\title{
Rediscovering Sculptures from Tebtynis at the Museo Egizio in Turin
}

\author{
Giorgia Cafici, Giulia Deotto
}

This article presents three case studies from an ongoing research project on the statues and sculptural fragments from Tebtynis, discovered by Carlo Anti in the years 1930-1936 in the temple dedicated to the god Soknebtynis. Specifically, it examines the following three statues: Alexandria, Graeco-Roman Museum inv. no. 22979, Turin, Museo Egizio S. 18176, and a non-royal statue which one of the authors has recently identified as Turin, Museo Egizio S. 19400+S. 19400/1. The authors combine stylistic analysis with a study of relevant archival records currently kept in Padua and Venice, Italy, to shed light on these sculptures and retrace their post-excavation history.

$$
\text { ملخص البحث: }
$$

The present article is the result of a collaboration between the Museo Egizio in Turin, the Scuola Normale Superiore in Pisa and the Università degli Studi di Padova. ${ }^{1}$ It aims to offer some preliminary results of an ongoing research project focusing on the sculptures and sculptural fragments discovered at Tebtynis by Carlo Anti (Villafranca di Verona, 1889 - Padua, 1961), professor of Archaeology at the Università degli Studi di Padova and director of the Missione Archeologica Italiana in Egypt (19281936). ${ }^{2}$ The project aims to retrace the post-excavation history of these sculptures and provide an indepth analysis of their features and archaeological context. The investigation is being conducted using an interdisciplinary approach combining a thorough stylistic analysis with the study of the archival records related to Anti's fieldwork at Tebtynis now preserved in Padua and Venice.

This paper presents three case studies from this on- going research project. More specifically, it examines three sculptures discovered in 1931 in the area near and around the entrance to the temenos of the temple of the god Soknebtynis (Fig. 1), namely: Alexandria,

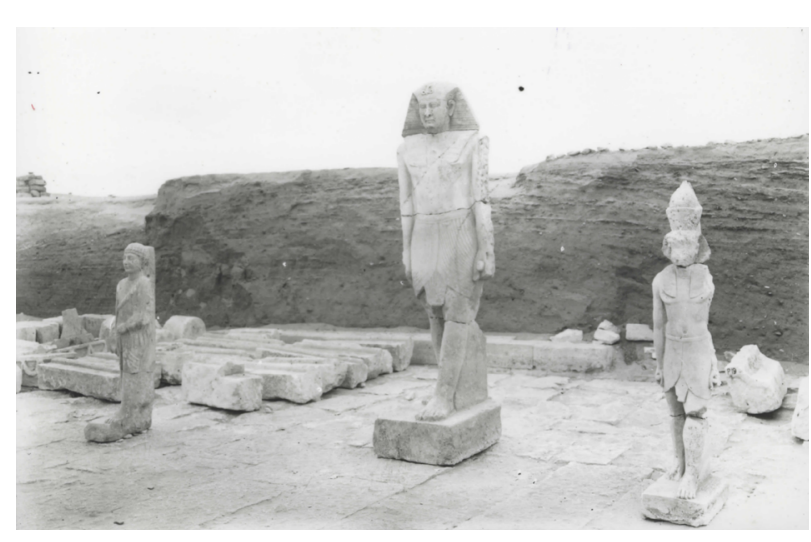

Fig. 1. The two royal sculptures and the non-royal statue in the vestibule of the temple. MSA-Fondo Anti inv. no. Box1Sparsa126, No. 184. Photo n. 14. Under concession by the Università degli Studi di Padova. All rights reserved. 
Graeco-Roman Museum inv. no. 22979; ${ }^{3}$ Turin, Museo Egizio S. 18176 (Cat. 1); and Turin, Museo Egizio S. 19400 + Turin, Museo Egizio S. 19400/01 (Cat. 2), recently rediscovered in the museum. The first two sculptures depict two pharaohs, easily recognizable by their royal attributes, and the third a non-royal figure, which Anti originally identified as a priest.

The paper is divided into three main sections and two catalogue entries. The first section describes the discovery of the statues and the archaeological context as they emerge from the archival records related to Anti's fieldwork at Tebtynis. The three statues are discussed here in order of discovery, following Anti's report on the 1931 season. Two blocks of limestone and a Greek inscription are also taken into account to test Anti's hypothesis - put forward in notes written mostly after the excavation - of an original link between the statues and these elements. The second section retraces the post-excavation history of the two sculptures now in Turin through a study of published and unpublished documents. The third section provides a stylistic analysis of the statues and proposes a date for them. Finally, the catalogue entries offer the first detailed publication (editio princeps) of the two statues now held at the Museo Egizio in Turin. The study of these two sculptures is based on direct examination and on photographs taken at the time of the discovery and now preserved in Padua. ${ }^{4}$

G.C., G.D.

\section{Discovery and archaeological context}

The ancient village of Tebtynis, present-day Umm el-Breighât, is located in the southern area of the Fayum. It was probably founded during the Middle Kingdom, around 1800 BC, but it flourished during the Graeco-Roman period as an agricultural and religious centre with a great temple, devoted to the god Soknebtynis. ${ }^{5}$ It was continuously inhabited until the 11th century $\mathrm{AD}$, when it was abandoned because of the advance of the desert.

This area was already mentioned in 1819 by Giovan Battista Belzoni, ${ }^{6}$ but was first explored only in 1899 by Bernard Pyne Grenfell and Arthur Surridge Hunt. ${ }^{7}$ It was later investigated by Otto Rubensohn, ${ }^{8}$ in 1902, and Evaristo Breccia in 1929. ${ }^{9}$ The site was then systematically excavated by Carlo Anti and his assistant Gilbert Bagnani from 1930 to 1936. After the Second World War, it remained abandoned for decades, until 1988, when the Università degli Studi di Milano and the IFAO resumed work at the site. One of the first aims of the French-Italian team was to study the documentation from previous excavations, notably the folders related to the fieldwork at Tebtynis preserved in the Anti archive at the Università degli Studi di Padova. ${ }^{10}$ However, the team only had access to a part of Anti's whole archive, since after his death this had been split amongst three locations, namely, the Museo di Scienze Archeologiche e d'Arte dell'Università degli Studi di Padova (MSA, Padua), the Istituto Veneto di Scienze Lettere ed Arti, located in Venice (IVSLA), and the Musei Civici agli Eremitani in Padua. ${ }^{11}$

Only in recent years have scholars finally managed to examine the whole range of documents related to the seven campaigns directed by Anti at Tebtynis. $^{12} 1769$ photographs, 121 slides, 26 plans and technical drawings, 1514 papers, including notes, letters, reports and preliminary studies and one cinematographic film have been traced in the holdings of the Museo di Scienze Archeologiche e d'Arte dell'Università degli Studi di Padova and (by the author of the present section) at the Istituto Veneto di Scienze Lettere ed Arti. Careful study of this recently discovered documentation has allowed the author of this section to reconstruct the activities of the Italian archaeological team in Egypt in the Thirties of the last century and to locate the exact find-spots of the objects.

Carlo Anti excavated at Tebtynis when he was director of the Missione Archeologica Italiana in Egypt. He was appointed to this position in 1928, after the death of the previous director, Ernesto Schiaparelli. After the first few years, which he devoted to studying the work previously done by the Italian mission, and a first excavation in Ptolemais (Menschiah) in $1929,{ }^{13}$ he decided to work in Tebtynis in collaboration with the Istituto Papirologico (currently Istituto Papirologico “G. Vitelli”, Florence). This collaboration was made possible by an agreement with Girolamo Vitelli and Evaristo Breccia. ${ }^{14}$

Anti personally directed three campaigns (19301932). In 1932 he became Rector of the Università degli Studi di Padova and consequently had to re- 


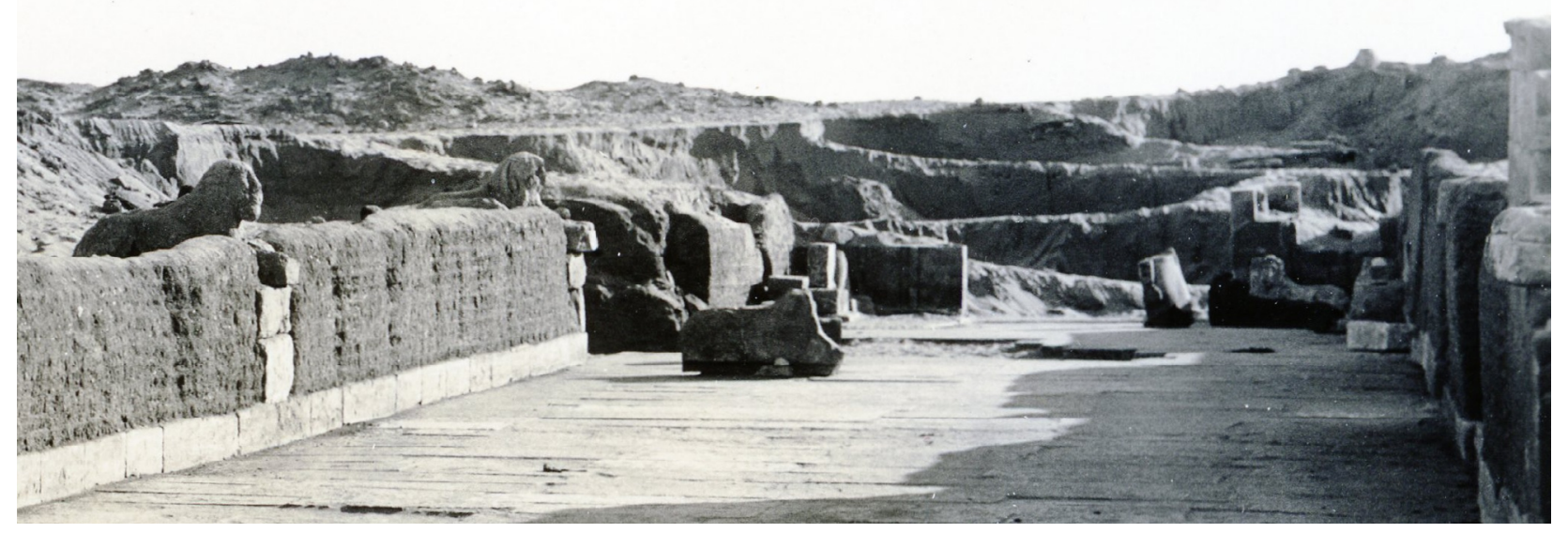

Fig. 2. Photograph taken shortly after the discovery of the vestibule of the temple, 1931. MSA-Fondo Anti inv. no. Box1sparsa064. Under concession by the Università degli Studi di Padova. All rights reserved.

main in Italy. He therefore appointed Gilbert Bagnani director of the fieldwork.

During his first campaign, Anti worked in the urban area and the southern necropolis. In his second and third campaigns, in 1931 and 1932, he discovered and dug the temenos and temple of the god Soknebtynis.

The 1931 campaign, which is the one relevant to the present article, started on the 9th of January and ended on the 4th of April, Anti was joined by architect Fausto Franco and archaeologist Gilbert Bagnani. ${ }^{15}$ The team also included some Egyptians, namely, Michel Bolos Ghattas and his father - the latter of whom had previously worked with Schiaparelli - as well as several local workers. ${ }^{16}$

During the entire campaign the workers were divided into groups and assigned to different zones. Anti's team photographed the structures and the artefacts as soon as they were cleared from the sand (Fig. 2), while Fausto Franco drew sketches of the buildings on sheets of paper. These sketches were combined at the end of the campaign into a general plan of the temple and its annexes. On this plan, Anti wrote the numbers assigned to the rooms found within the temenos and information related to the objects discovered therein (Fig. 3). ${ }^{17}$

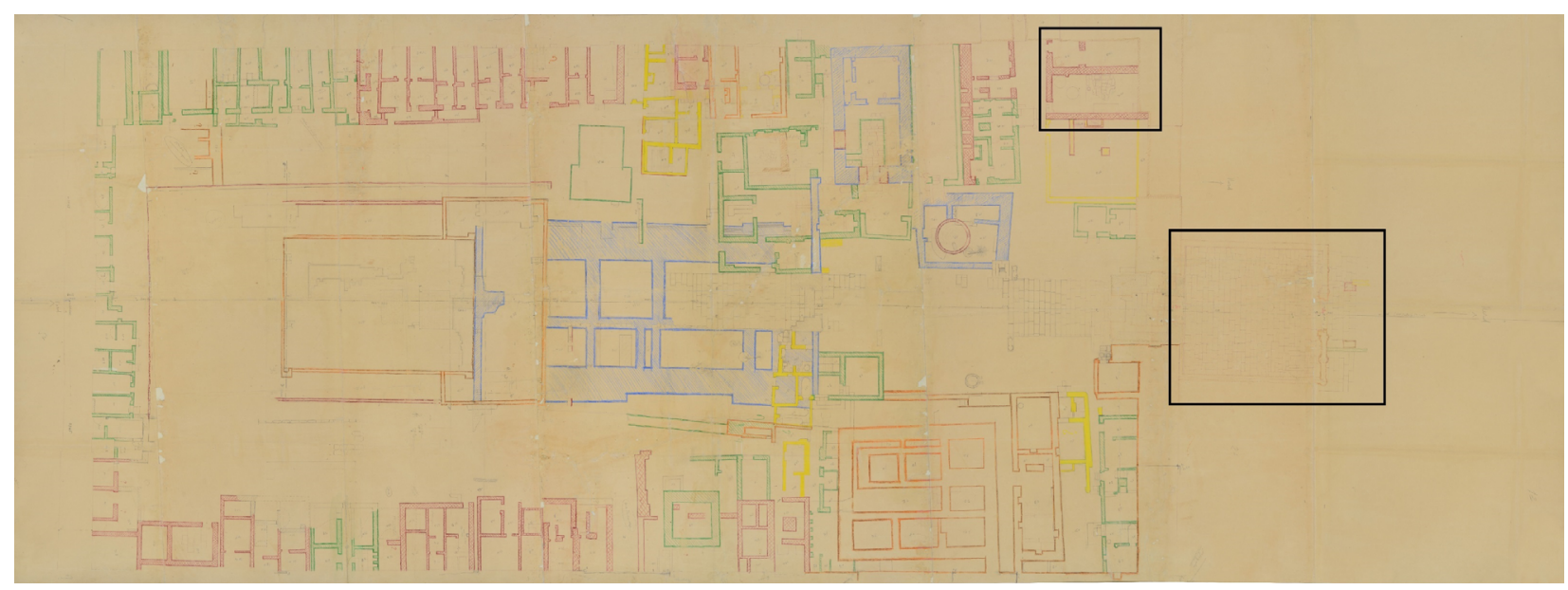

Fig. 3. Fausto Franco's general plan of the temple; the box highlights the vestibule of the temple and Room 12 (at the top). MSA, Anti's archive, map n. 1. Under concession by the Università degli Studi di Padova. All rights reserved. 
The first period of the 1931 campaign was devoted to uncovering the area near the western housing blocks, unearthed in 1930 - called "Scavo Nuovo" in Anti's reports. Anti was persuaded that these blocks were arranged around a square with a marketplace (Fig. 4). When he came across hall-like structures, he initially called them "temples" in his reports. Only later on, after the discovery of the vestibule of the temple of Soknebtynis, did he correctly recognize them as deipneteria arranged on either side of a dromos. $^{18}$

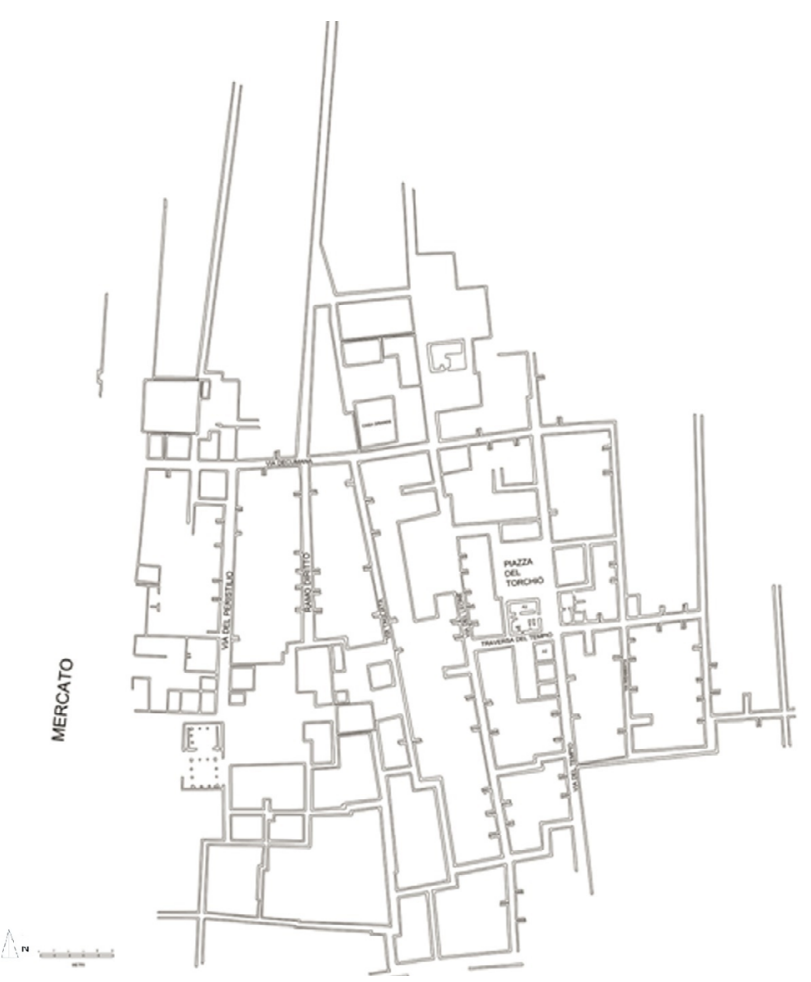

Fig. 4. Fausto Franco's map of Tebtynis, 1931. MSA, fondo Anti, inv. no. 267 (adapted version by G. Deotto). Under concession by the Università degli Studi di Padova. All rights reserved.

The discovery of the "South Temple", the so-called vestibule, was reported in several papers published by Anti after the 1931 campaign $^{19}$ or preserved unpublished in his archive, ${ }^{20}$ and was crucial for the reconstruction of the town plan of Tebtynis, due to its position within the urban fabric. The vestibule was a small open court located at the beginning of the dromos, at the main entrance of the temenos. Its walls were decorated with reliefs showing the pharaoh offering to the god Sobek, and priests and other non-royal individuals attending the feast in honour of the god. It was excavated from the $26^{\text {th }}$ of January till mid-February, when the pylons, the entrance of the temenos, were found.

As Anti's report informs us, several decorative and architectural elements probably belonging to the vestibule were discovered in this area. Some of them were still in situ, such as the reliefs carved on the walls, but most of the decoration was found scattered in fragments. Two statues depicting a pharaoh and another depicting a non-royal individual were discovered in fragments in the area between the $30^{\text {th }}$ of January and the $24^{\text {th }}$ of February. ${ }^{21}$

The archive documents, mostly unpublished, highlight Anti's interest in these statues and in ancient sculpture in general. Statuary was indeed one of his main fields of study, as illustrated, for example, by his designing and publication of the statuary display in the Museo Archeologico Nazionale di Venezia ${ }^{22}$ or by his various publications on African Art, Near Eastern Studies or Classical Art, which are especially focused on ancient sculpture. ${ }^{23}$ The archive documents bear witness to the painstaking care Anti took in examining the three sculptures and to the method he used for their study. He noted down every stylistic detail (colours, hairstyle, eyes, hands and feet), ${ }^{24}$ and all useful information relative to their discovery, including the date. We can thus present the sculptures here following their chronological order of discovery. Moreover, during the campaign the fragmented statues were partially restored in order to be docu-



Fig. 5. Front of the vestibule of the temple. East pedestal and feet of statue Alexandria, Graeco-Roman Museum inv. no. 22979. MSA, Fondo Anti, inv. no. 186. Photo 001. Under concession by the Università degli Studi di Padova. All rights reserved. 


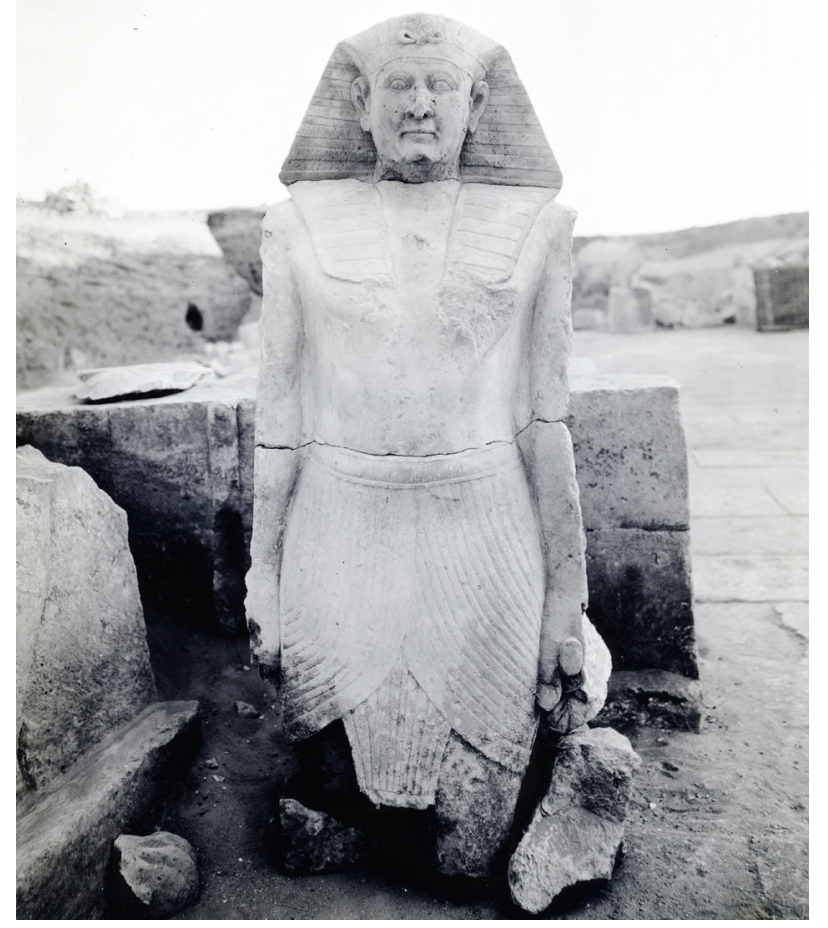

Fig. 6. Front of the vestibule of the temple. Statue Alexandria, Graeco-Roman Museum, inv. no. 22979. MSA, Fondo Anti, inv. no. Box1Sparsa125. Under concession by the Università degli Studi di Padova. All rights reserved.

mented and photographed, and an excavation number was assigned to each.

The first statue to be discovered, now in the Graeco-Roman Museum in Alexandria (inv. no. 22979), was found broken in four parts. The shins and feet were in situ, as Anti reports, between the east wall of the dromos and the entrance to the vestibule (Fig. 5). The second part, a fragment extending from the knee to the hip, lay inverted near the first. The third and fourth fragments, respectively the torso and the head, were found near the west pylon (Fig. 6). ${ }^{25}$ The statue, partially recomposed during the excavation, was extensively photographed (Fig. 7) and also makes a fleeting appearance in a film shot by the Istituto Luce at the end of the campaign. ${ }^{26}$

This sculpture was not in the Italian share of the partage. It had its own excavation number (T 31. 312) and was inserted in a list of items requested for transfer to Italy, along with other objects from Tebtynis. ${ }^{27}$ In this list, a Journal d'entrée number (JE 55960) was added

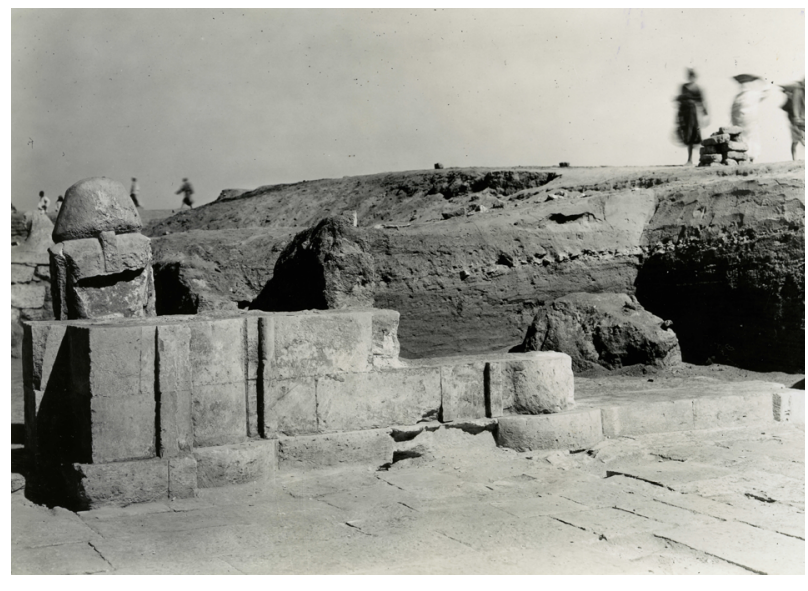

Fig. 7. Back view of statue Alexandria, Graeco-Roman Museum, inv. no. 22979. MSA-Fondo Anti inv. no. 282. Photo no. 17. Under concession by the Università degli Studi di Padova. All rights reserved.

in red ink, as for all the finds that Anti had intended to send to Italy, but which the Service des Antiquités de l'Égypte decided instead to keep in Egypt. After the end of the campaign, the statue was thus sent to the Cairo Egyptian Museum, but was subsequently moved to the Graeco-Roman Museum in Alexandria. Its presence in Alexandria was reported in a letter written by Evaristo Breccia to Anti dated 17 April $1931^{28}$ and is confirmed by a second letter sent in 1933, where Anti asked Achille Adriani, who had succeeded Breccia as director of the Museum, for information about the exact dimensions of the statue, which by this time had probably been completely restored. ${ }^{29}$ The second royal statue (Turin, Museo Egizio S. 18176, Cat. 1) was found broken in three parts. Two were in the vesti-

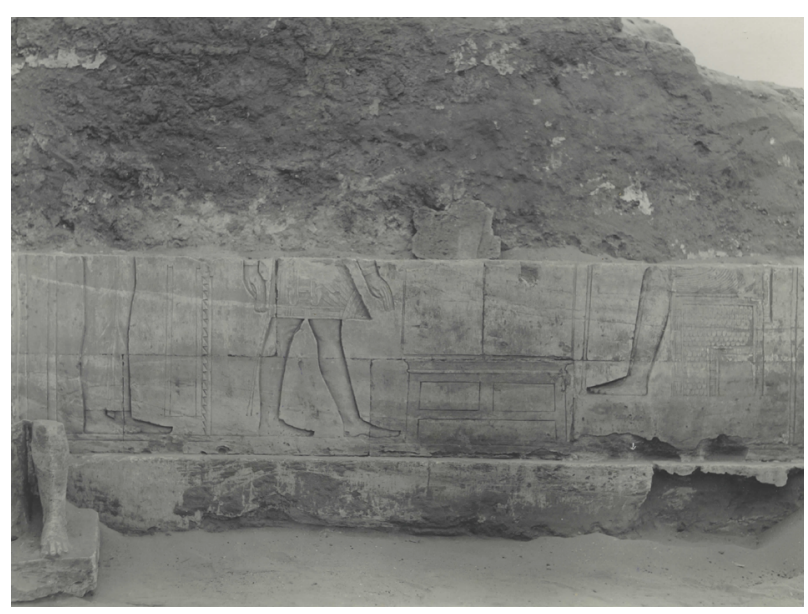

Fig. 8. Feet of royal statue Turin, Museo Egizio S. 18176 inside the vestibule of the temple. MSA-Fondo Anti inv. no. 281. Photo n. 009. Under concession by the Università degli Studi di Padova. All rights reserved. 


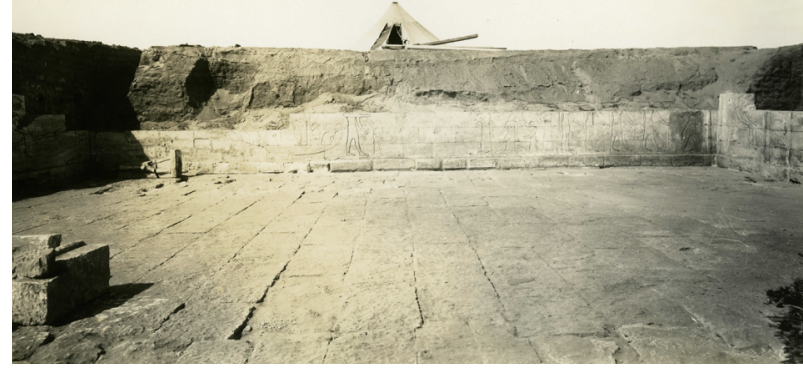

Fig. 9. Vestibule of the temple. On the left: royal statue Turin, Museo Egizio S. 18176, put back together during the 1931 season. MSA-Fondo Anti inv. no. 282. Photo n. 024. Under concession by the Università degli Studi di Padova. All rights reserved.

bule $^{30}$ (Figs. 8, 9), while the head was inside a room in the northwest building of the first court of the temple's temenos, designated as number 12 in Franco's map ${ }^{31}$ (Fig. 3). It was found in a layer of rubbish, related to the use of Room 12 as a stable before the abandonment of the site. Anti hypothesized that the destruction of this sculpture dated back to ancient times, without being more specific as to the time of this destruction. ${ }^{32}$

After its discovery, this sculpture was earmarked for the Italian share of the partage and included in the list of items requested for transfer to Italy, where it is referred to by its excavation number, $\mathrm{T}$ 31.313. In this case, Anti was granted permission to send it to his country. ${ }^{33}$
Finally, Anti's team also unearthed three fragments ${ }^{34}$ of a third statue (Cat. 2) inside the vestibule. This sculpture was described by Anti as a portrait of a priest. ${ }^{35}$ It was included in the abovementioned list of items as number $\mathrm{T} 31.314$ and also sent to Italy following the partage. ${ }^{36}$

Thus, the fragments belonging to all of these sculptures were found in different locations within the site and reassembled during the campaign. Indeed, Anti regarded these three statues as a group, mentioning and studying them together both during the campaign and after its end, as the documents from his archive attest. ${ }^{37}$ Furthermore, he studied the three sculptures with a care which he did not devote to other items discovered at the site. The fragments were photographed after their discovery and each statue was then recomposed and moved to the vestibule to be individually photographed. A black sheet was held up behind the statues by two Egyptian workers to provide a background against which they would stand out more (Figs. 15-20).

Anti also linked the statues with other elements found separately in the area near and around the vestibule, notably two squared blocks of limestone and a Greek inscription relative to Ptolemy XII. These elements should hence also be taken into consideration to understand Anti's views about the area and the original location of the statues.

Anti found the two squared blocks in the area in front of the vestibule. They were made of two types of limestone, one dark-coloured and hard, the other light-coloured, soft and fragile. After the discovery



Fig. 10. Detail of Fausto Franco's general plan of the temple. MSA, Fondo Anti, inv. no. plan01 (adapted version by A. Meleri - Horus Project). Under concession by the Università degli Studi di Padova. All rights reserved. 
of the statues, he identified them as pedestals. He tried to date these elements, regarding the pedestals as belonging to an earlier chronological phase than the paving of the processional street. Unfortunately, he suggested only a relative chronology, not an absolute one. ${ }^{38}$

The two square blocks of different sizes are clearly recognizable in Fausto Franco's general plan of the temple of Soknebtynis (Fig. 3 and Fig. 10), respectively on the east and west side of the entrance to the vestibule. ${ }^{39}$ It is also easy to recognize the east pedestal in some photographs from Anti's archive relative to the discovery of the royal statue now held in Alexandria (Fig. 5). Fragments of this statue were indeed unearthed close to the east pedestal, as reported in Anti's papers. ${ }^{40}$

Finally, a Greek inscription relative to Ptolemy XII was found, together with other blocks of stone, near the west pedestal, in the corner between the entrance to the vestibule and the west wall of the dromos (Fig. 11). ${ }^{41}$ As a consequence, the block with the inscription was considered by Anti to be one of the collapsed elements of the west pedestal itself. ${ }^{42}$ This block had the shape of an irregular parallelepiped. ${ }^{43}$ In its description, Anti assigns a letter to each of its sides, except for the one interpreted as its back: the letter $\mathrm{A}$ thus indicates the face of the block with the inscription, while the letters $\mathrm{B}$ and $\mathrm{C}$ designate the sides. The irregular shape, the presence of gypsum on the unpolished back of the block, and the kind of limestone, which is different from that used in the vestibule, allowed Anti to hypothesize that it was part of the west pedestal, which was made of different blocks of the same limestone as that of the inscribed block. ${ }^{44}$ Moreover, the dimensions reported by Anti for the pedestal and the inscription are compatible..$^{45}$ Once in Italy, Anti reconsidered the original location of the royal sculptures, supposing a connection between the two pedestals and the two statues of pharaohs found in 1931. Unfortunately, only few notes are available on this topic, since he was not able to complete and publish the study. ${ }^{46}$

Our study of Anti's notes, photographs and plans allows us to reassess Anti's hypotheses regarding the original location of the sculptures. Anti identified the two blocks at the entrance of the vestibule as pedestals. He attributed the Greek inscription in honor

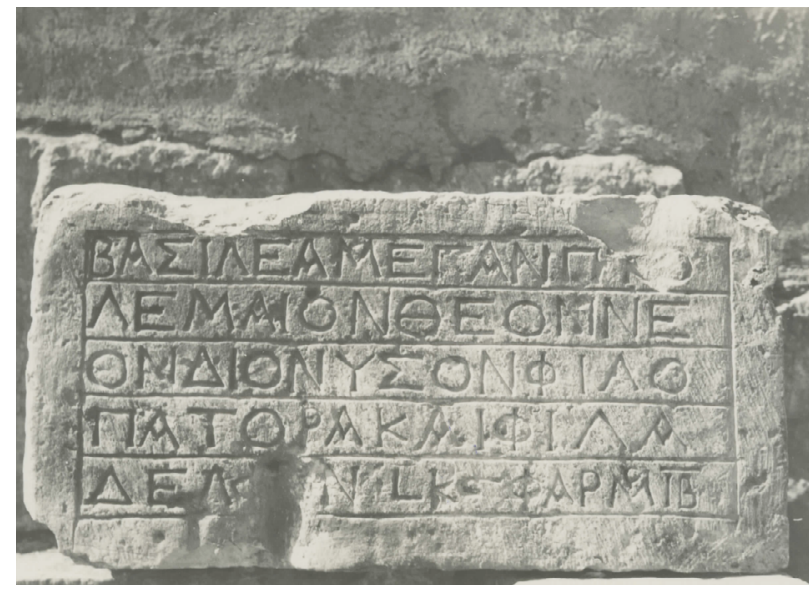

Fig. 11. Greek inscription related to Ptolemy XII. MSA, Fondo Anti, inv. no. 289. Photo 001. Under concession by the Università degli Studi di Padova. All rights reserved.

of Ptolemy XII to the western one, as the inscription was found near it, was made of the same material, and its shape and measurements were compatible with this attribution. The eastern one, instead, he identified as the pedestal of the colossal royal statue discovered in fragments around it in $1931 .{ }^{47}$ Both of these hypotheses seem indeed plausible. ${ }^{48}$

The fragments of the royal statue now in the Museo Egizio in Turin (S. 18176, Cat. 1 in the present article) were mostly found inside the vestibule. ${ }^{49}$ As a consequence, Anti's hypothesis that it originally stood at the entrance of the vestibule and was paired with the other royal statue lacks confirmation. It seems more likely that it originally stood inside the vestibule. ${ }^{50}$ Finally, Anti did not speculate about the position of the non-royal statue (Cat. 2). However, the archive documents indicate that all its fragments were found inside the vestibule; it is thus likely that this was also the original location of this sculpture.

G.D.

\section{Post-excavation history}

The archival documentation also sheds light on the post-excavation history of the sculptures. The records reveal that the three sculptures went separate ways immediately after their discovery ${ }^{51}$ and allow us to retrace the history of the two statues sent to Italy. More precisely, a private letter sent from Gilbert Bagnani to Carlo Anti and a second letter written by the latter to Guido Calza reports that the non-royal sculpture was displayed in an exhibition held in Rome in $1932 . .^{52}$ The title of the exhibition is not 
mentioned in the letters, but the reference to Rome and to Villa Giulia, and the date of the letter sent by Bagnani have allowed the author of this section to identify the exhibition as the Mostra d'arte antica, Roma, Galleria Nazionale a Valle Giulia, April-June $1932,{ }^{53}$ organized to showcase the growth of Italian archaeological and art-historical activities in the years 1922-32. ${ }^{54}$ As explicitly acknowledged in its catalogue, the exhibition did not display the objects in chronological order or according to specific scientific criteria, and included modern European drawings and paintings along with ancient Greek, Roman, Italic and Etruscan artefacts. ${ }^{55}$ Four items discovered at Tebtynis were displayed in Room IX among other sculptures, namely, a statue of a pharaoh, a statue of a priest and two Coptic column capitals. Unfortunately, these objects are neither photographed nor thoroughly described in the catalogue, which only mentions their provenance, the name of the director of the archaeological mission who discovered them and the year of discovery. ${ }^{56}$ However, thanks to the documents held in Anti's archive we do know that the "statuetta di sacerdote" displayed in Rome wears a fringed draped garment ${ }^{57}$ and that the Italian archaeologist discovered only one such sculpture at Tebtynis. The identification of the statue displayed in Rome in 1932 with the non-royal statue studied here (see below, Cat. 2) is therefore indisputable. Due to its provenance from the same site and archaeological season, it is also virtually certain that the pharaoh displayed in the exhibition was the smaller and more poorly preserved of the two royal sculptures discovered by Anti in 1931, now held in the Museo Egizio in Turin (Cat. 1).

Over the four decades following this exhibition, this material from Tebtynis seems to have been forgotten, until 1972; in that year, the late Silvio Curto, director of the Museo Egizio in Turin, discovered some boxes containing Tebtynis items in the Museo Nazionale Romano in Rome. The Superintendent of the antiquities of Rome at the time, Gianfilippo Carettoni, had these objects transferred to Turin to be stored in the Museo Egizio, where they still are today. ${ }^{58}$

In Turin, the royal sculpture, inventoried with the number S. 18176, has been exhibited in the permanent display ever since its arrival, and is currently shown in Room XII. The non-royal statue, instead, was stored in the basement of the museum awaiting restoration, probably due both to its original poor state of preservation and to damages suffered after its excavation. However, since then its whereabouts remained unknown to scholars. In 2004, Vincent Rondot briefly described the non-royal sculpture discovered at Tebtynis "uniquement à partir des photographies d'archives [...] cette statue est aujourd'hui presque entièrement détruite. Les photographies d'archives montrent qu'elle était déjà très érodée au moment de sa découverte et je n’ai pu la retrouver entière dans aucun des musées où elle pourrait être conservée, Le Caire, Alexandrie ou Turin"; he added that "dans la réserve du musée de Turin consacrée aux objets de Tebtynis est conservée une tête très pulvérulente dont tout indique qu'il s'agit de la tête de notre statue",59 adding that the fragment was "sans numéro". 60

In February 2016, the author of the present essay had the opportunity to look at some Ptolemaic sculptures held in the Museo Egizio in Turin. One of the aims of this visit was to locate the sculptural fragment described by Vincent Rondot as the head of the non-royal sculpture discovered at Tebtynis. The investigation started with a search in the internal database of the museum, which allowed the author to identify the head of the non-royal sculpture with sculptural fragment S. 19400. The database indicates the item as originating from Anti and Bagnani's excavations at Tebtynis and having been given to the Museo Egizio by the Museo Nazionale Romano. The measurements given (h. 24, w. 13, d. 23.5) closely match those indicated by Rondot for his "tête très pulvérulente" ${ }^{61}$ (Fig. 12). Autopsy of the object further confirmed this identification. ${ }^{62}$

The sculptural fragment is poorly preserved because of the friable state of its material. The left side of the head is almost completely lost. In the central part of the face one can still discern remains of the hair and of a crown of oval treble leaves. The wide almond-shaped eyes with the elongated outer corner are still unmistakably visible. The nose is long and narrow. The round and full cheeks are poorly preserved but still clearly distinguishable. The ears are both lost, as is the lower right part of the head. The mouth and chin are partially lost and the parts that survive are poorly preserved. The back of the head 


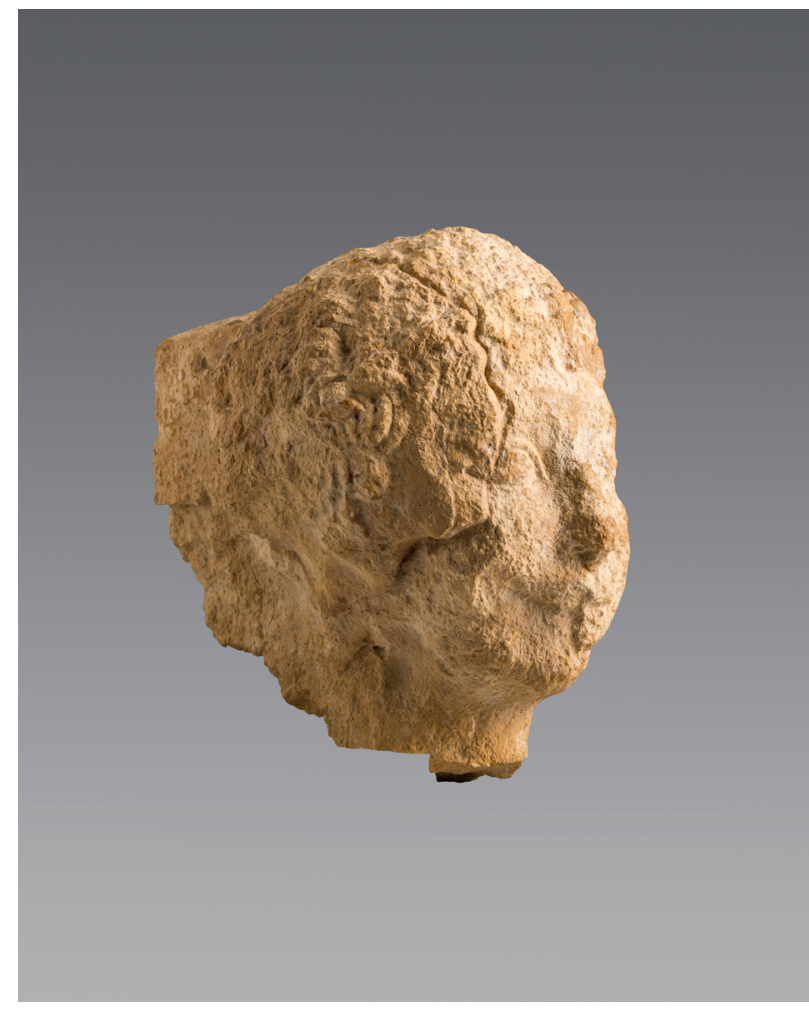

Fig. 12. Turin, Museo Egizio S. 19400 (head). Photo by Nicola Dell'Aquila/Museo Egizio.

retains the trapezoidal top of the uninscribed back pillar. Traces of red pigment are clearly visible on the right side of the head. These appear to be very similar to the pigments found on the royal statue from Tebtynis that is presently also in the Turin museum. ${ }^{63}$

Research in the museum also revealed the presence of another object numbered with the same inventory number as the limestone head, with the addition of sub-number "/01". ${ }^{64}$ Like the head, the database identified it as having been acquired by Anti and having been transferred to the Museo Egizio from the Museo Nazionale Romano. The state of preservation of the artefact is very poor and conservation action is envisaged in the near future. On account of this, the autopsy of the object was initially impossible, and a preliminary analysis had to be based on the photographs available in the museum's files (Fig. 13). They show the headless statue inside the crate in which it was transported from Rome to Turin. The photographs show that on the outer right side of the crate used to hang a reproduction of the picture from Anti's archive showing the head of the non-royal sculpture from Tebtynis (Fig. 13 and Fig. 26).

This detail confirms that when the body and head arrived from Rome they were known to belong to

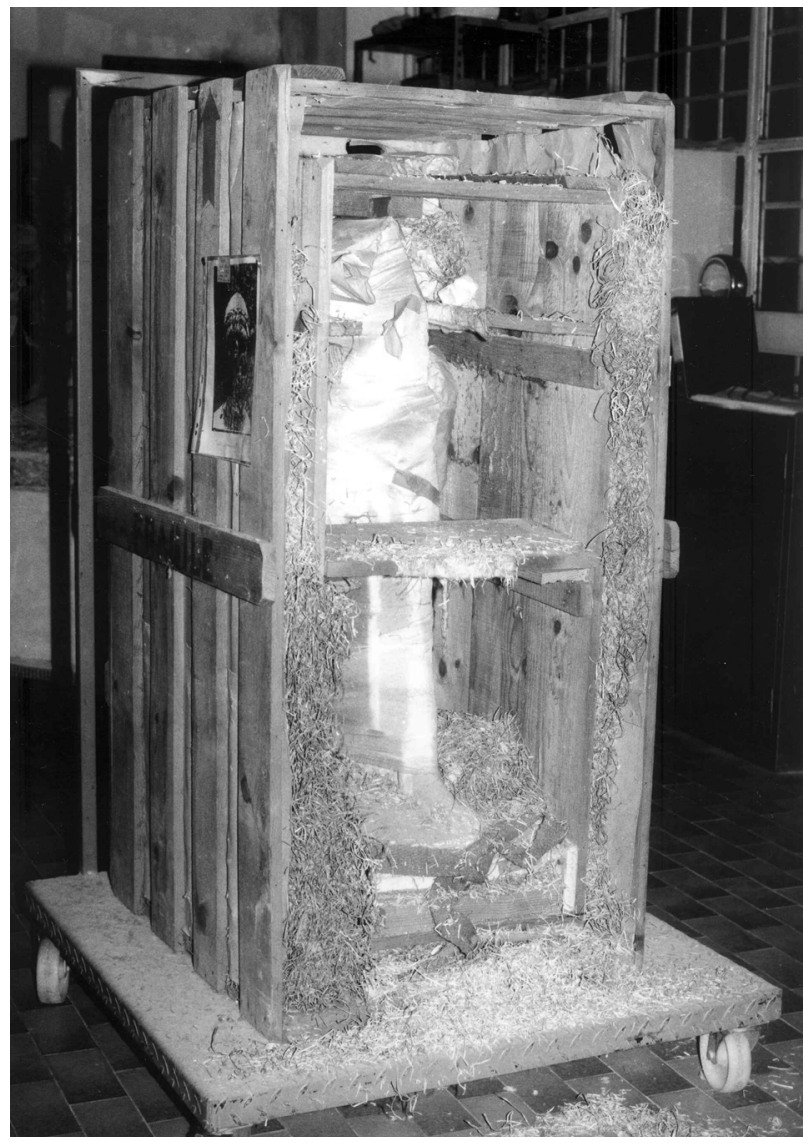

Fig. 13. Turin, Museo Egizio S. 19400/01 (body) inside its crate. Photo from a conservation report by the Nicola workshop in Aramengo (Province of Turin).

Photo Nicola Restauri/Museo Egizio.

the same statue, and their provenance from Anti's excavation at Tebtynis was also known. Accordingly, the same inventory number was assigned to the body and the head. However, doubts still lingered about the identification of Turin, Museo Egizio, S. 19400/01 with the body of the non-royal statue from Tebtynis, due to the fact that in the available photographs the artefact was completely covered by a protective wrap, except for the broad feet with long toes and merely incised square toenails. Feet carved in this manner are found on all three of the limestone statues discussed in the present paper, and may indeed characterize all sculpture made at Tebtynis between the late Ptolemaic Period and early Roman Era. Direct viewing of the object was consequently needed in order to definitively confirm the identification.

The crate containing object Turin, Museo Egizio S. 19400/01 was opened on 23 March 2017. It contained an acephalous statue completely covered by a protective wrap, except for the feet. The reproduc- 
tion of the picture from Anti's archive showing the head of the non-royal sculpture from Tebtynis (Fig. 26) was hung on the right side of the inner case.

The removal of the protective wrap revealed the poorly preserved body of the non-royal statue from Tebtynis (Fig. 14).

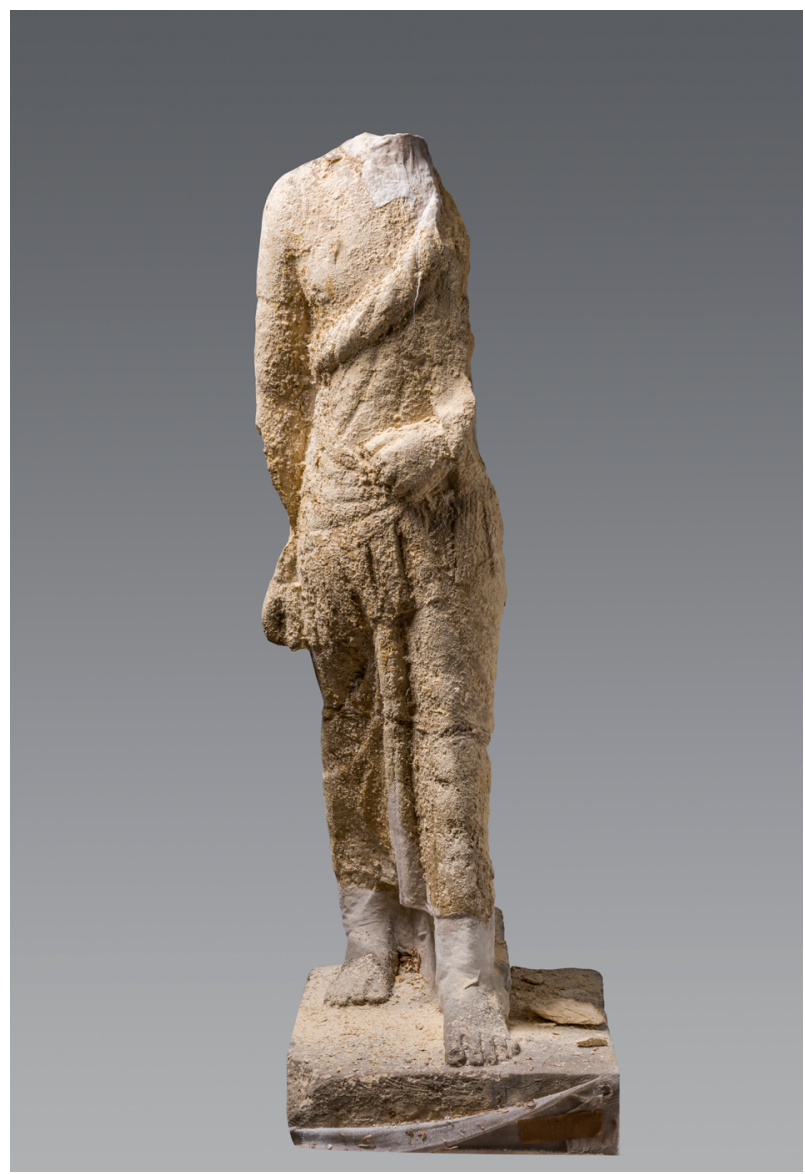

Fig. 14. Turin, Museo Egizio S. 19400/01. Photo by Nicola Dell'Aquila/Museo Egizio.

The surface of the sculpture is highly damaged. The left shoulder and the left arm are unfortunately totally lost. The lower part of the right forearm is missing. However, the main features of the statue are still unmistakable (cf. Fig. 24). The drapery of the garments and the modelled outer edge of the cloak are mostly preserved. Oblique pleats are still evident on the outer part of the cloak wrapped around the left shoulder and on the right side of the torso, while five semi-circular pleats are incised on the right hip. Trapezoidal fringes with individually carved strands are clearly visible along the edge of the cloak. The pleats falling downwards are evident on both sides of the skirt. The thick ankles and the solid and broad feet charac- terized by toes with squared nails are well preserved. The identification of this fragment with the body of the statue discovered by Anti is thus certain. ${ }^{65}$

G.C.

\section{Stylistic analysis}

From a stylistic point of view, the three statues undoubtedly share several features. Unfortunately, their poor state of preservation has resulted in the loss of some of their features. More precisely, the torso and arms of Alexandria, Graeco-Roman Museum inv. no. 22979 (Fig. 6 and Fig. 18) and the head and the arms of Turin, Museo Egizio S. 18176 (Figs. $15,16,17$ ) are poorly preserved and their details are not distinguishable even in the photographs taken by Anti immediately after the discovery. Furthermore, the torso of the non-royal statue is covered by the garment and is thus not comparable with the naked torsos of the royal statues. Nevertheless, a stylistic analysis of the facial features and lower limbs of these statues can help to date them.

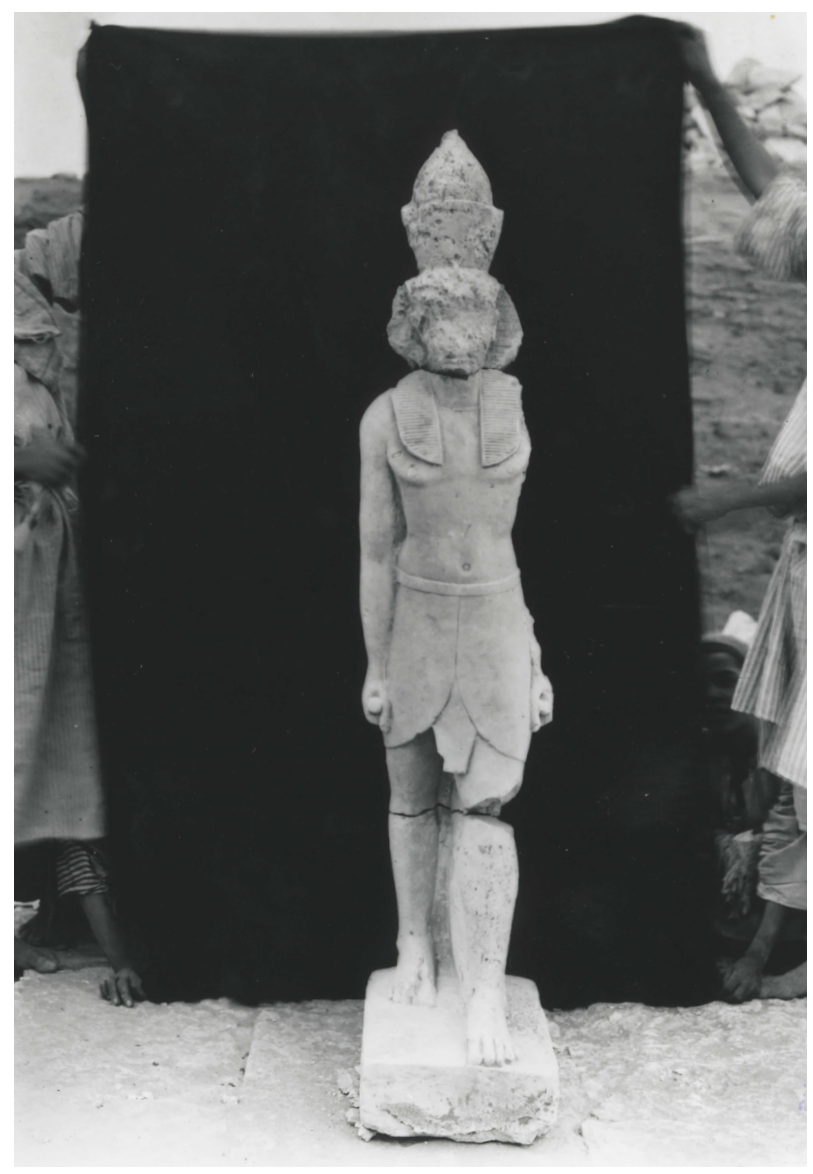

Fig. 15. Turin, Museo Egizio S. 18176. MSA-Fondo Anti inv. no. 184. Photo n. 04. Under concession by the Università degli Studi di Padova. All rights reserved. 


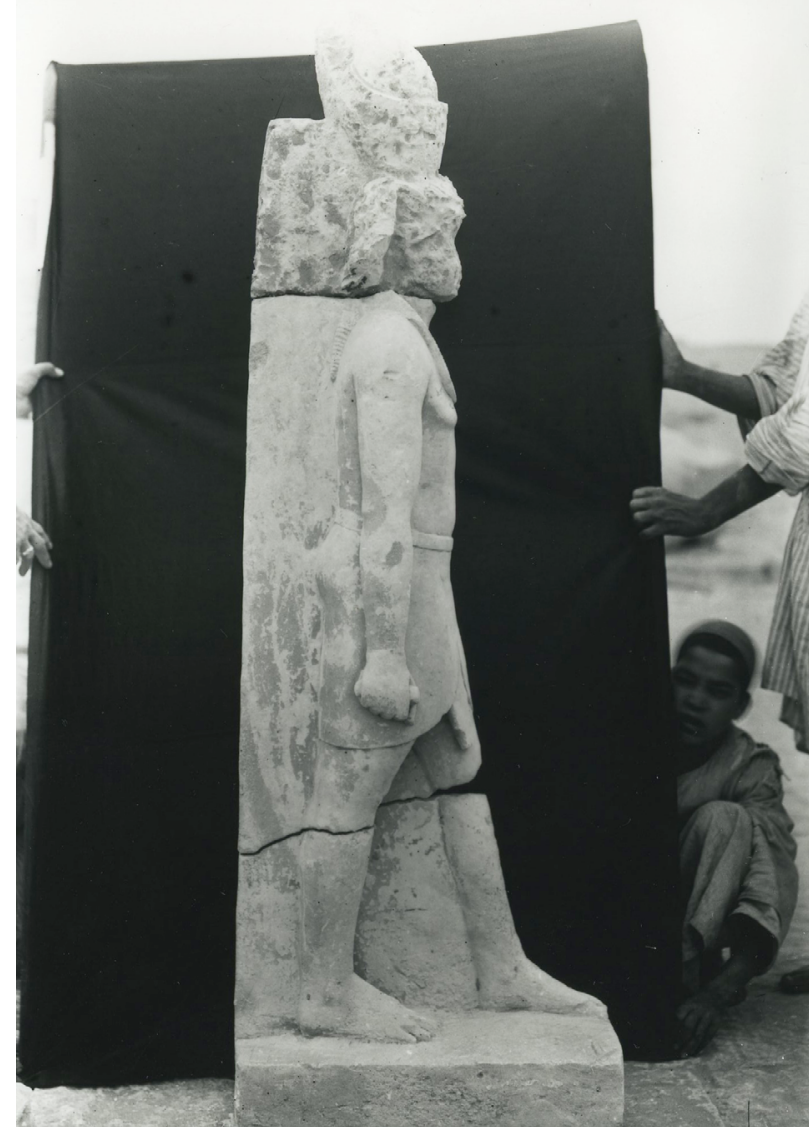

Fig. 16. Turin, Museo Egizio S. 18176. MSA-Fondo Anti inv. no. 184. Photo n. 16. Under concession by the Università degli Studi di Padova. All rights reserved.

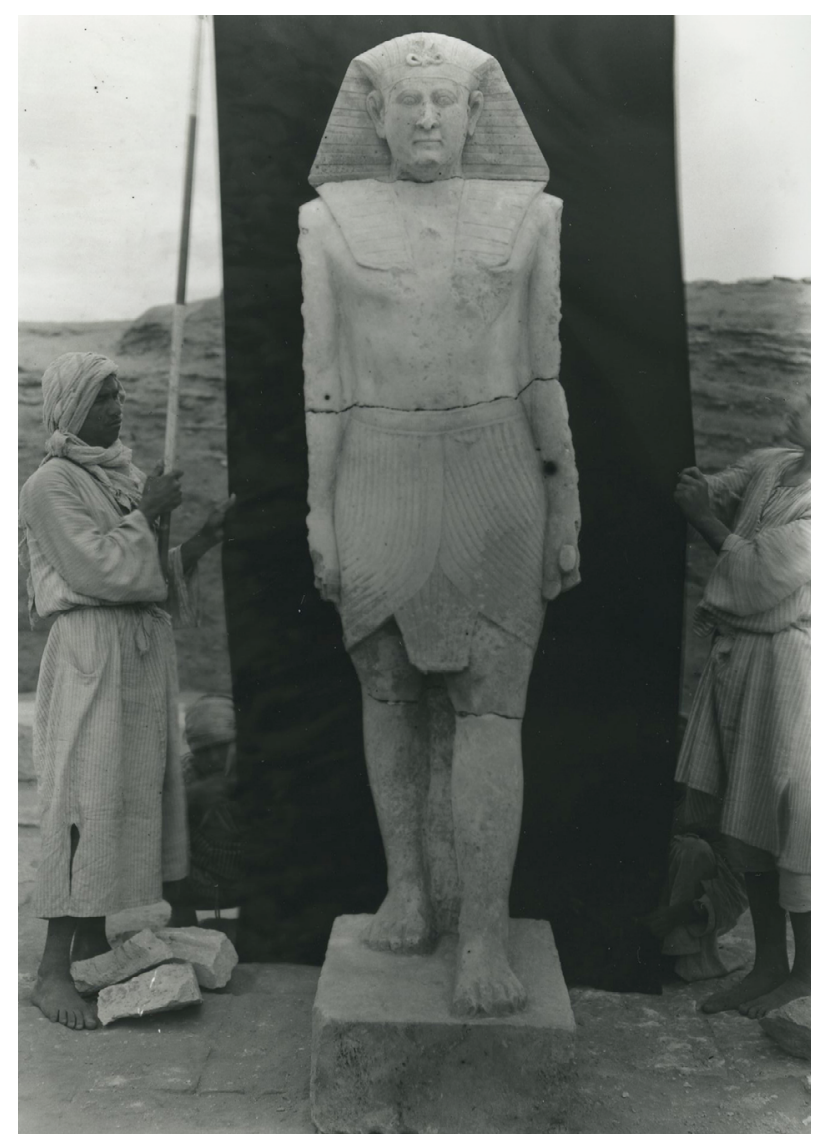

Fig. 18. Alexandria, Graeco-Roman Museum inv. no. 22979. MSA-Fondo Anti inv. no. 184. Photo n. 17. Under concession by the Università degli Studi di Padova. All rights reserved.

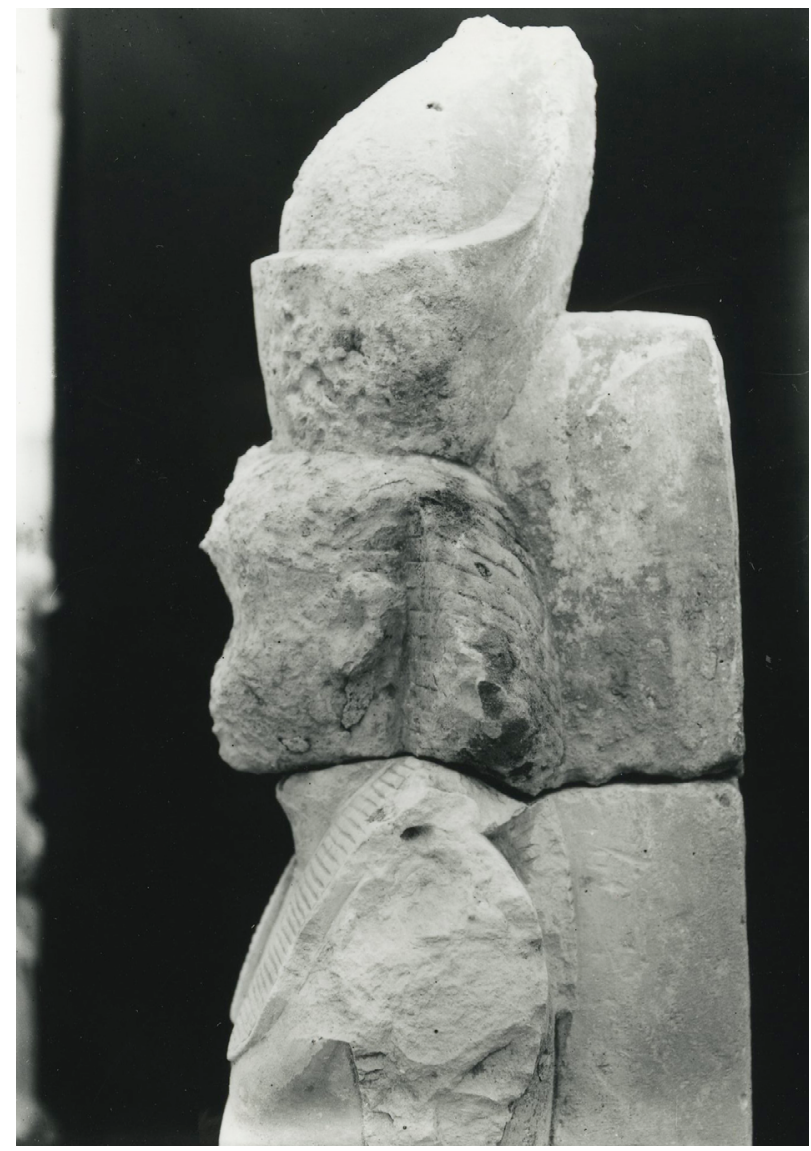

Fig. 17. Turin, Museo Egizio S. 18176. MSA-Fondo Anti inv. no. 184. Photo n. 06. Under concession

by the Università degli Studi di Padova. All rights reserved.

The royal statue held in the Graeco-Roman Museum in Alexandria (Figs. 18, 19, 20 ) is characterized by realistic facial traits. The head is large and square. The forehead is narrow and characterized by a wrinkle rendered by means of a single horizontal line. The arched and finely carved eyebrows run from the inner to the outer corner of the eyes. The eyes are wide, almond-shaped and elongated. Their outline is modelled in relief. The pupils are carved. ${ }^{66}$ The partly damaged nose is hooked, broad and long, with wide wings. The nasolabial furrows are rendered by means of two diagonal lines running from the wings of the nose to the corner of the mouth. The cheeks are full and the ears are broad, with stylized details such as helix, antihelix, tragus, antitragus and lobule. The mouth is wide and characterized by thin lips. The upper lip is slightly turned down. The chin is partially damaged but it was originally broad and pointed. 


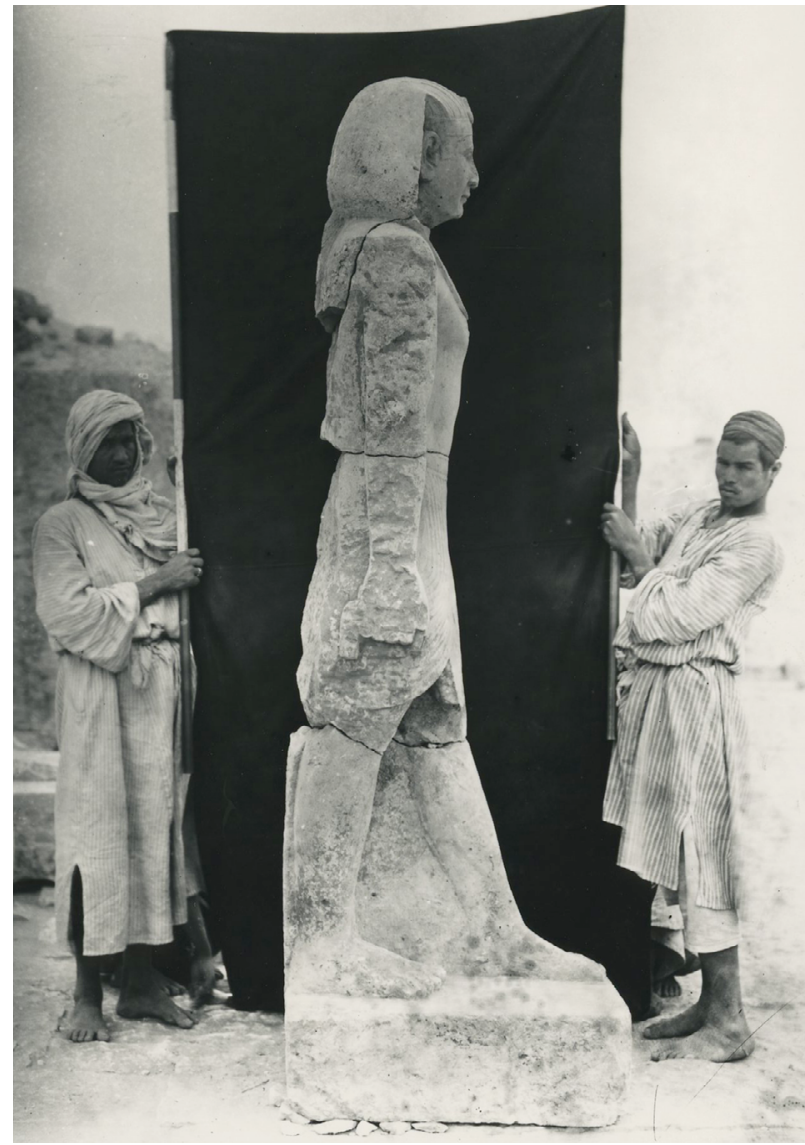

Fig. 19. Alexandria, Graeco-Roman Museum inv. no. 22979. MSA-Fondo Anti inv. no. 184. Photo n. 19. Under concession by the Università degli Studi di Padova. All rights reserved.

Scholars have commonly identified this portrait with that of Ptolemy XII (80-58 and 55-51 BC), ${ }^{67}$ highlighting strong similarities between the profile of the statue and the portraits of this ruler found on coins. ${ }^{68}$ This identification appears to be correct. The royal statue is indeed characterized by a long and hooked nose and a pointed small chin. These peculiar features are not widely attested on royal Ptolemaic portraits and are particularly distinctive of Ptolemy XII's portrait on coins, ${ }^{69}$ as shown on the obverse of silver coin Boston, Museum of Fine Arts inv. no. 53.456, ${ }^{70}$ which belongs to the one basic coin type known for this sovereign. In it, Ptolemy is characterized by thick irregular curls, a hooked nose and a small round chin. ${ }^{71}$ Moreover, the wide-open eyes and the arched eyebrows that reach the outer corner of the eyes are typical of the portrait type struck on coins of Ptolemy XII as shown on a silver coin in the British Museum (London, British Museum inv. no. 1987,0649.520). ${ }^{72}$ This coin's portrait and the Alexandria statue specifically share another significant

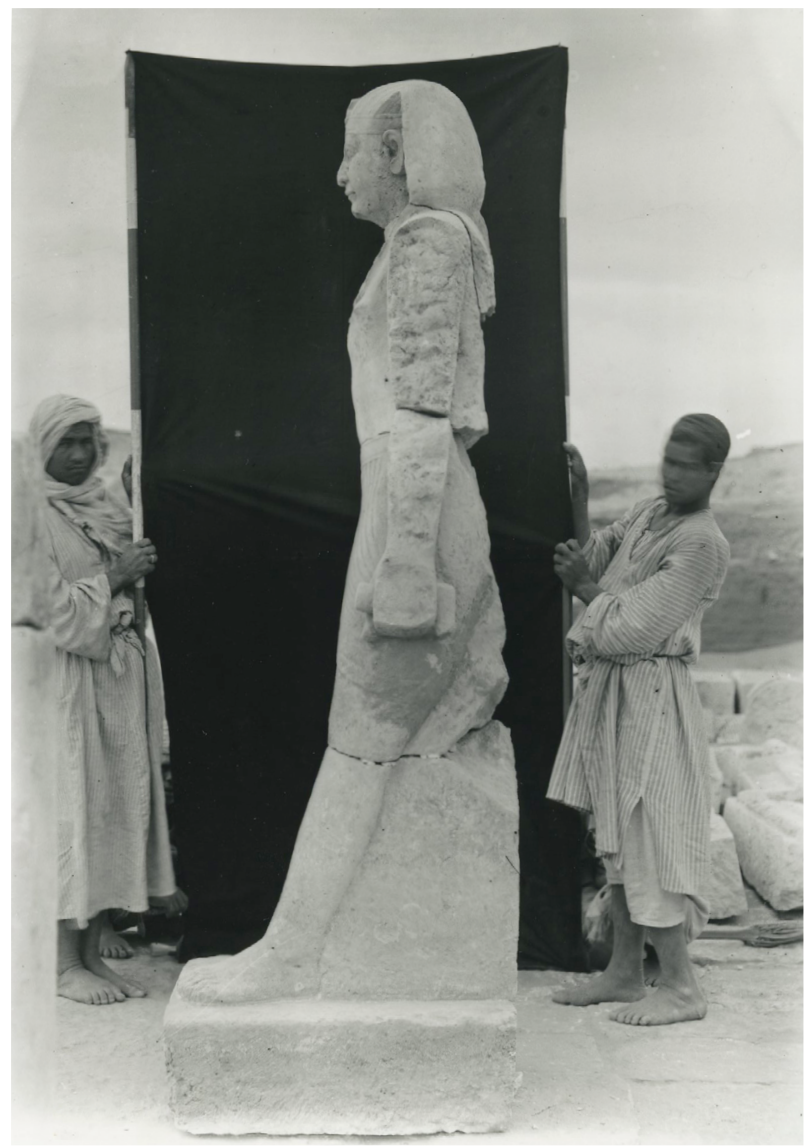

Fig. 20. Alexandria, Graeco-Roman Museum inv. no. 22979. MSA-Fondo Anti inv. no. 184. Photo n. 18. Under concession by the Università degli Studi di Padova. All rights reserved.

feature: the round rendering of the eye pupils. Unfortunately, any reliable comparison with sculptural portraits of Ptolemy XII is impossible due to the absence of statues surely identified by inscriptions or archaeological context. Although some sculpted heads are plausibly attributed to this sovereign by scholars (Alexandria, Graeco-Roman Museum inv. no. $11275^{73}$ and Louvre Ma $3449,{ }^{74}$ to cite only few examples), their identification is based only on stylistic criteria and on comparisons with portraits on coins. Only the latter can thus be regarded as certainly depicting Ptolemy XII.

More significantly, in the same area of the vestibule where this sculpture was discovered Anti found (also in 1931) an inscribed rectangular limestone block $^{75}$ (Fig. 11), identified by Guido Bastianini and Claudio Gallazzi as part of the statue's pedestal. ${ }^{76}$ It bears five lines of a Greek honorary inscription dedicated to Ptolemy XII. The inscription is framed by horizontal lines and its guidelines are still visible. The text reads as follows: 


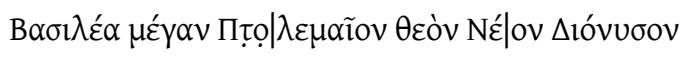

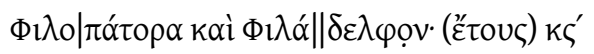

$\Phi \propto \rho \mu о(\tilde{v} \theta \imath) \imath \beta^{\prime 77}$

The great king Ptolemy, Theos Neos Dionysos

Philopator and Philadelphos. Year 26, 12(th day) of Pharmouthis [April 15, 55 BC].

The inscription's formula, with the name of the ruler in the accusative, his titles and the date, is a commonly attested format for honorary inscriptions carved on the base of royal statues. ${ }^{78}$ Incidentally, this inscription is the most ancient record of the second part of the reign of Ptolemy XII (55-51 BC). ${ }^{79}$ The current whereabouts of this block are unknown and some scholars suppose it is now lost. ${ }^{80}$ The block was not found in situ during the archaeological excavations carried out at Tebtynis in 1988 by the Istituto di Papirologia dell’Università di Milano with the Institut Français d’Archéologie Orientale du Caire. The objects discovered at Tebtynis by Anti between 1930 and 1936 were divided up between Egypt and Italy, ${ }^{81}$ but so far the inscription has not surfaced in any museum of either country. Thus, all existing studies of it are based on the photographs taken by Carlo Anti. ${ }^{82}$

The connection between the block with the inscription dedicated to Ptolemy XII and the statue Alexandria, Graeco-Roman Museum inv. no. 22979 remains possible, but is far from certain. According to Anti's notes on the discovery of the block, it was found on the west side of the entrance to the vestibule, whereas the statue was found on its east side. ${ }^{83}$ According to Anti's records, as mentioned above, two square blocks made of two different varieties of limestone were also found on the east and west sides of the entrance to the vestibule (Fig. 10). ${ }^{84}$ The Italian archaeologist hypothesized the presence of two statues, one for each side of the entrance, and did not link the inscribed block with the royal statue now held in Alexandria. ${ }^{85}$ Anti's hypothesis that another, now lost statue of Ptolemy XII stood at the entrance of the vestibule and that the inscription was relative to this statue is certainly appealing. The two limestone blocks are very similar in shape and dimensions, ${ }^{86}$ and are symmetrically positioned on either side of the entrance to the vestibule. Further- more, the dimensions of the plinth of statue Alexandria, Graeco-Roman Museum inv. no. 22979 are compatible with the size of the east pedestal, just as the dimensions of the west pedestal are compatible with the size of the block with the inscription. ${ }^{87}$ The identification of the two limestone blocks as statues pedestals seems thus virtually certain. However, the relationship between the statue, the pedestals and the inscription remains uncertain and needs further investigation.

Even without the match with the inscription, the identification of the character portrayed in this statue with Ptolemy XII seems virtually certain, as shown above through the highlighting of the strong similarities between its facial features and the portraits of that pharaoh on coins. Some of the facial features of the royal statue held in Alexandria are also found in the non-royal sculpture found in the vestibule of the temple of the god Soknebtynis. Both have a full and squared head, arched eyebrows, wide, almond-shaped eyes with elongated outer corners and a long narrow nose. However, the two sculptures look quite different. The royal statue reproduces the physiognomic features of the ruler, while the non-royal one does not show any realistic facial details that would allow the identification of the person portrayed. As to the head of the royal statue held in Turin, its facial features are completely ruined and no identification with known rulers is hence possible.

The three sculptures are furthermore characterized by an analogous modelling of the lower limbs. The legs are massive with calves clearly outlined. The details of the ankles are clearly visible. The feet are broad, with long toes displaying squared nails (cf. Cat. 1-2).

The stylistic analysis of the two preserved heads and of the three bodies thus highlights strong similarities and suggests that the three sculptures should approximately date to the same period. Unfortunately, none of them bears an inscription. However, the virtually certain identification of the ruler portrayed in the statue held in Alexandria with Ptolemy XII suggests that all three sculptures were probably made during the reigns of the last Ptolemies (80-30 BC ca.).

G.C. 


\section{Final considerations}

These first results of our research project on the sculptures and sculptural fragments discovered by Carlo Anti at Tebtynis highlight the crucial importance of studying the original artifacts in conjunction with the archival and photographic documentation relative to them. The usefulness of this approach was already exhaustively explained by Jaromir Malek at the end of the last century. ${ }^{88} \mathrm{Ac}-$ cording to this scholar, "in addition to the troika of monuments in situ, material in museums and publications, archives constitute Egyptology's fourth estate. These four categories are the main sources of information for the study of ancient Egypt, each with its own characteristics and peculiarities, but none dispensable". ${ }^{89}$ Malek's statement is grounded in his awareness of the destruction or deterioration of many ancient Egyptian monuments over time and of the loss of information in situ. The only hope of recovering at least some of these data is to search for them in records left by early travellers and Egyptologists. Notes, drawings, papers, watercolors and photographs invariably record monuments when they were better preserved than today. Some were published in articles or reports, but much of this documentation is unpublished and this information hence only exists in archives. ${ }^{90}$

In this specific case, the information relative to Tebtynis sculptures in Anti's archive is particularly bountiful, thanks to the scholar's vigilant precision and his special interest in statuary. We were thus able to uncover previously unknown details about the discovery, material features and post-excavation history of the three statues. Anti's notes give the exact place of discovery of the fragments of each statue and some of their previously unknown movements following their discovery. Moreover, the study of the photographic material in Anti's archive and direct observation of the statues allowed us to propose a date for them and to certainly identify sculptural fragment Turin, Museo Egizio S. 19400 with the head of the non-royal statue found in 1931 and sculptural fragment Turin, Museo Egizio S. 19400/01 with its body.

The research is still ongoing and a number of issues need further investigation. ${ }^{91}$ We will be carrying out additional work in the context of this multidiscipli- nary approach and study the entire corpus of sculptures discovered by Anti at Tebtynis. We will further analyse the archaeological context, the possible link between all the sculptural elements found in the area of the temple (including limestone blocks and inscriptions), and the original setting of the statues. The resulting comprehensive study will shed light on the cultural and artistic function of these statues inside the temple area.

G.C., G.D.

\section{Cat. 1. Royal statue}

(Fig. 21, Figs. 15-17)

Turin, Museo Egizio S. 18176.

From Tebtynis, area of the vestibule of the temple of the god Soknebtynis. Discovered by Carlo Anti in 1931.

Excavation number: T 31.313.

80-30 BC ca.

Unidentifiable pharaoh.

Limestone.

H: $164 \mathrm{~cm},{ }^{92} \mathrm{~W}: 35 \mathrm{~cm}, \mathrm{D}: 55.7 \mathrm{~cm}$.

\section{Essential bibliography: ${ }^{93}$}

Rondot, Tebtynis II, pp. 136, 274, figs. 100-02.

This poorly preserved life-size statue was found broken into three fragments, from the top of the double crown to the neck, from the neck to the knees, and from the knees to the base, and was reassembled with cement. In 2012, the statue was cleaned and reinforced by the Doneux e Soci company, ${ }^{94}$ and is now displayed in Room XII of the Museo Egizio in Turin. The following description of the features of the statue is based on the photographic material in the Anti archive and on the author's direct observation of the sculpture.

The sculpture depicts a striding male figure with the left leg forward and the arms held straight down along the body. The character wears royal attributes, including a double crown, a banded nemes and a plain shendyt fastened by a narrow belt. The face is very damaged, the facial features being barely visible. This poor preservation makes an identification of the ruler portrayed impossible. Similarly, the double crown, the upper section of the nemes and the lower section of the legs are poorly preserved. The 



Fig. 21. Turin, Museo Egizio inv. no. S. 18176. Photo by Nicola Dell'Aquila and Federico Taverni/Museo Egizio.

lateral sections of the nemes, the left arm and the knees are partly lost. The double crown is wide and finely modelled. Vincent Rondot mentions remains of a uraeus "à la base de la couronne rouge", ${ }^{95}$ which are now barely visible. The horizontal bands of the nemes are thicker above and thinner below. Differences within the decorative pattern of the same nemes are attested in Egypt since the third millennium $\mathrm{BC},{ }^{96}$ and nemes headdresses showing this variation in pattern are often found in combination with the double crown since pharaonic times. ${ }^{97} \mathrm{~A}$ similar rendering of the nemes can be observed in other Ptolemaic royal sculptures, such as a statue from Tanis ${ }^{98}$ and the head of a sphinx also coming from the Fayum region. ${ }^{99}$ There is no hair coming out of the frontlet. The poorly preserved head still shows full, round cheeks and thick lips. The torso is naked and modelled in detail. A horizontal line in relief at the base of the neck is probably the remaining part of a collar. The king's shoulders are broad and slightly drooping. The pectorals are full and squared and the nipples engraved in the shape of shallow circles with the inner circle in relief. The torso is tripar- tite, ${ }^{100}$ the chest, rib cage and abdominal region beis clearly marked, the abdomen slightly protruding and the navel carved as a deep circle. The arms are adjacent to the hips and the stone between each arm and the upper part of the torso was not removed. The muscles are not clearly defined in that only their outline is barely visible. The elbow pit and the wrist of the right arm are clearly marked. Part of the left arm was partly restored at an unspecified time after discovery. The thumbs of both hands are characterized by incised squared nails. The plain shendyt covers the upper part of the thighs. These are massive, with clearly outlined calves. The right knee is poorly preserved, but the detailed kneecap is still visible. The left knee was crudely restored at an unspecified time after discovery. The ankles are anatomically modelled. The feet are wide and characterized by long carved toes with merely incised square nails. The first three toes of the right foot are missing. The back of the statue is worked in detail, with the bands of the nemes and the perimeter of the shen$d y t$ worked with the same accuracy as on the front 
of the sculpture. The back is characterized by a wide, uninscribed back pillar, which reaches up to the central section of the headdress. The top of the back pillar is poorly preserved. It currently appears to be slightly rounded, but the Anti archive photographs seem to show that it was originally rectangular; its current shape is thus probably the result of post-excavation wear. The rectangular base is thick. Small traces of red pigment can be made out in some areas of the surface of the statue. These were first noticed by Vincent Rondot and interpreted by him as a coating applied in order to imitate the appearance of Aswan red granite. ${ }^{101}$ These traces of pigment are now mostly visible on the sides of the back pillar, close to the areas on which conservation was done in the past.

The almost total loss of the facial features of the statue makes a stylistic analysis impossible. The torso is of a type frequently attested throughout the Ptolemaic Period and hence does not provide any help in dating the statue. Parallels include Amsterdam, Allard Pierson Museum inv. no. 7780 (attributed to Ptolemy VIII), ${ }^{102}$ London, British Museum EA 1209 (attributed to Ptolemy IV or Ptolemy IX), ${ }^{103}$ and Paris, Musée du Louvre A 28 (attributed to Ptolemy XII). ${ }^{104}$

The style of the limbs, instead, is more informative. The modelled calves and broad feet are also found in Alexandria, Graeco-Roman Museum inv. no. 22979, as well as Cat. 2 in the present article. The legs are particularly similar to those of the former statue. They are massive, with clearly outlined calves. The details of the ankles are clearly visible. The feet are broad and characterized by long carved toes. Both feet have engraved squared nails. These similarities make it likely that the three sculptures date approximately from the same period, namely the reigns of the last Ptolemies (80-30 BC ca.), thanks to the virtually certain identification of the ruler portrayed in Alexandria, Graeco-Roman Museum inv. no. 22979 with Ptolemy XII.

\section{Cat. 2. Private statue}

(Fig. 12, Figs. 22-27)

Turin, Museo Egizio S. 19400 (head) + S. 19400/01 (body).

From Tebtynis, area of the vestibule of the temple of the god Soknebtynis.

Discovered by Carlo Anti in 1931.

Excavation number: $\mathrm{T} 31.314$.

80-30 BC ca.

Non-royal figure.

Limestone.

H: about $130 \mathrm{~cm} .{ }^{105}$

Head (Turin, Museo Egizio S. 19400): H: 24 cm

W: $13 \mathrm{~cm} \mathrm{D:} 23 \mathrm{~cm}$.

Body (Turin, Museo Egizio S. 19400/01): H: $110 \mathrm{~cm}$ W: $22 \mathrm{~cm} \mathrm{D:} 48 \mathrm{~cm}$.

\section{Bibliography:}

Rondot, Tebtynis II, pp. 139, 277 figs. 108-111; Cafici, EVO 39, pp. 149-61.

This poorly preserved non-royal limestone sculpture was found broken in three fragments - top of head to neck, neck to knees, and knees to base, respectively - all discovered in the vestibule. ${ }^{106}$ The following description of the features of the statue is based on the photographic material in Anti's archive as well as direct observation of Turin, Museo Egizio S. $19400+$ Turin, Museo Egizio S. 19400/01.

The statue depicts a striding male figure with the left leg forward and a back pillar, uninscribed. The identity of the person portrayed is unknown due to the absence of inscriptions. He was surely a member of the local elite - e.g. a priest or local benefactor - but his status in the contemporary society of Tebtynis cannot be further specified. He wears a leaf crown and draped garments. The right arm hangs straight along the body, with the hand clenched into a fist. ${ }^{107}$ The left arm is bent across the abdomen, with the left hand grasping the edge of the cloak.

G.C. The head of the sculpture is wide and squared. The locks of hair are short and plastically modelled. The locks on the top, sides and back of the head are wavy and untidily arranged. Those on the forehead are straight and carefully arranged, and form three pincers resulting from the parting of locks (two above 

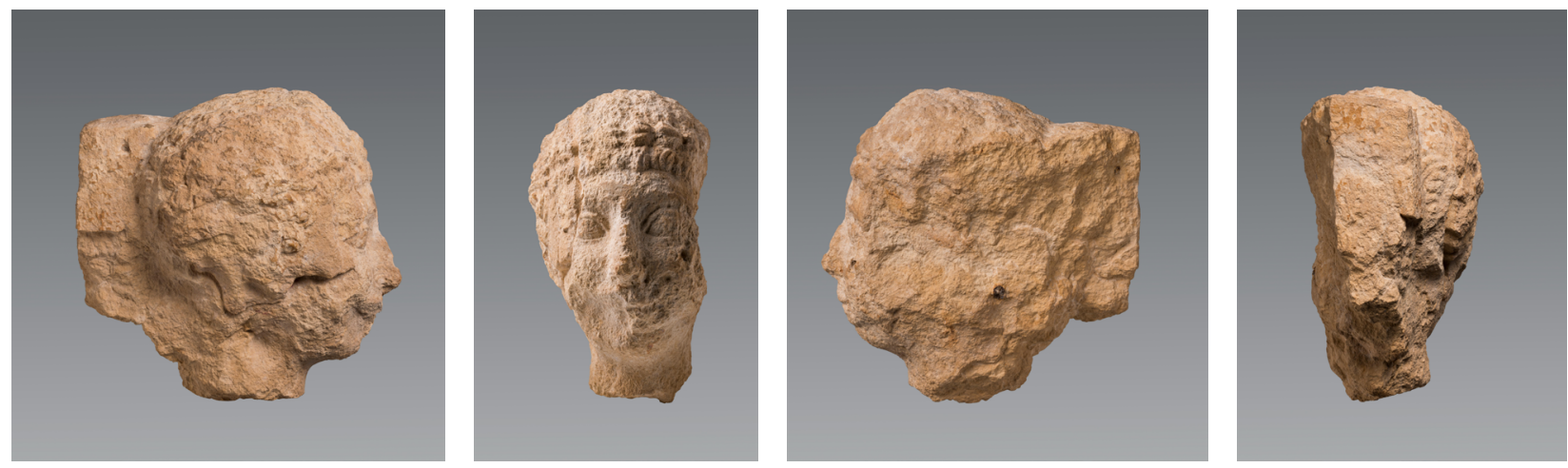

Fig. 22. Turin, Museo Egizio inv. no. S. 19400. Photo by Nicola Dell'Aquila/Museo Egizio.
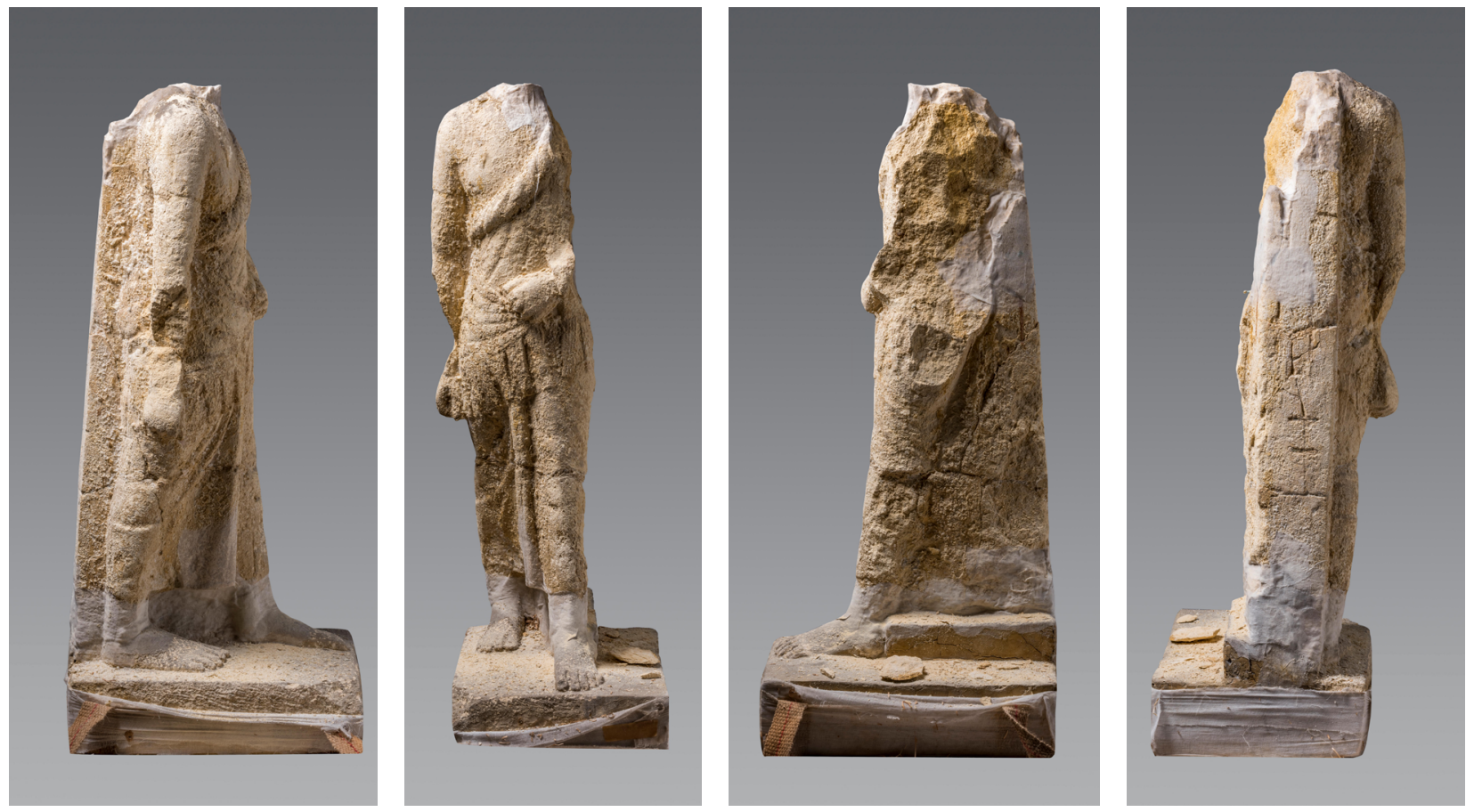

Fig. 23. Turin, Museo Egizio inv. no. S. 19400/01. Photo by Nicola Dell'Aquila and Federico Taverni/Museo Egizio.

the right eyebrow and one above the left). The hair on the forehead is parted by a knotted crown made of oval treble leaves, probably of laurel, with its far ends carved on the sides of the back pillar. ${ }^{108}$ The head does not show realistic facial features. The forehead is narrow and unwrinkled. The eyebrows are thin, arched and plastically modelled. The eyes are wide and almond-shaped, with the outer corner elongated and rimmed in relief. The upper eyelids are modelled in relief, while the lower eyelids are carved. The broad ears are protruding and their details are roughly rendered. The nose is long and narrow. The cheeks are round and full. The upper lip is thinner than the lower lip. The chin is barely modelled and the neck is thick and does not show any anatomical detail.
Due to the friable state of the stone, the head is poorly preserved. Its left side is almost completely lost. In the central part of the face one can still make out remains of the hair and of a crown of oval treble leaves. The details of the eyes, nose and cheeks are still visible. The ears are both lost, as is the lower right section of the head. The mouth and chin are partially lost, and the parts that survive are poorly preserved. The back of the head retains the trapezoidal top of the uninscribed back pillar. Traces of red pigment are clearly visible on the right side of the head. They appear very similar to those found on the Turin royal statue (Cat. 1). ${ }^{109}$

The individual portrayed wears a type of draped garment that is widely attested during the Ptolemaic Period. ${ }^{110}$ The clothes cover most of the body, in 


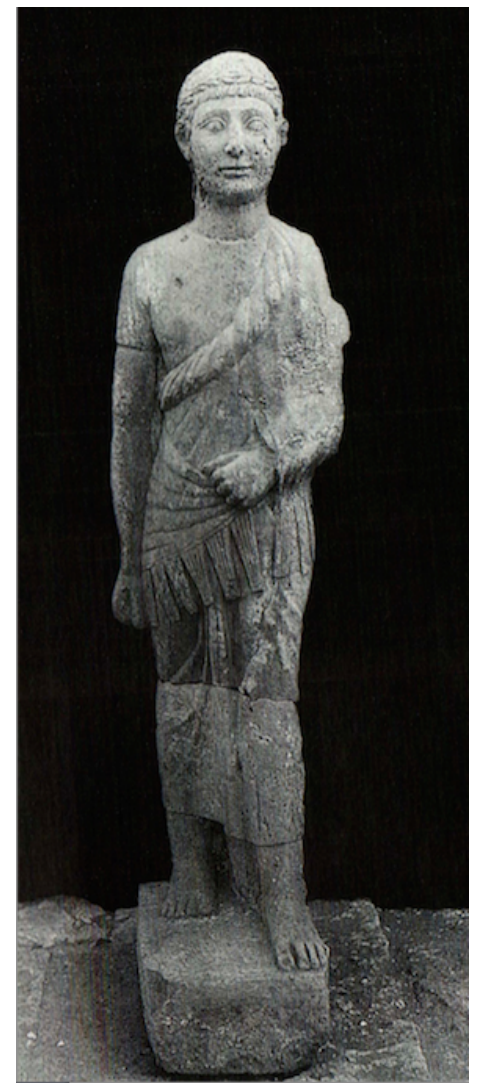

Fig. 24. Turin, Museo Egizio S. 19400+S. 19400/01-Fondo Anti inv. no. 184. Photo n. 10. Under concession by the Università degli Studi di Padova. All rights reserved.

that only the lower part of the right arm, the right forearm, the wrists, ankles and feet are exposed. The garment is composed of a short-sleeved undergarment with a round neck, a skirt tied around the lower part of the body and a fringed cloak draped around the torso, but leaving the right shoulder and right pectoral exposed. The shoulders are disproportionately narrow with respect to the head and the neck. Of the fingers of the right hand, only the downward stretched thumb is visible. The left hand holds the outer edge of the cloak; its knuckles are clearly visible and its thumb is stretched horizontally. The skirt does not seem to be fringed. ${ }^{111}$ The clearly visible anatomical details are the right arm and its elbow pit, the hands, the right pectoral, the left leg, the ankles and the feet. The drapery of the garments is geometrically rendered. The outer edge of the cloak is plastically modelled and covers the left shoulder and the upper part of the torso. Its upper part extends from the breastbone to the left shoulder and is characterized by vertical pleats running towards the left arm. The lower part of the cloak has oblique pleats. Similar pleats seem to be carved on the right side of



Fig. 25. Turin, Museo Egizio S. 19400+S. 19400/01-Fondo Anti inv. no. 184. Photo n.15. Under concession by the Università degli Studi di Padova. All rights reserved.

the torso, and five semi-circular pleats are engraved on the right hip. The edge of the cloak is graced with trapezoidal fringes with individually carved strands. The pleats of the skirt fall downwards; three are clearly visible on its right side. The ankles are broad and stout, and the toes of the broad feet have sharply rendered squared nails. The back pillar runs from the top of the head to the feet and does not bear any inscription or decoration. Direct observation of the sculpture shows that the back pillar originally had a trapezoidal top. The base is thick and is rectangular in shape. Its front is slightly rounded, probably as a result of post-excavation wear.

The state of preservation of the body of the non-royal statue is very poor. It was summarily restored by the Nicola Restauri firm between 9 December 2008 and 15 January $2009 .{ }^{112}$ The aim was exclusively to reinforce the object, as the restoration report explicitly states. The restorers thus decided to replace the old bandaging only where strictly necessary. The broken fragments were gathered in a box placed inside the crate. After the restoration, the crate with the sculpture was stored in the basement of the Museo Egizio. 


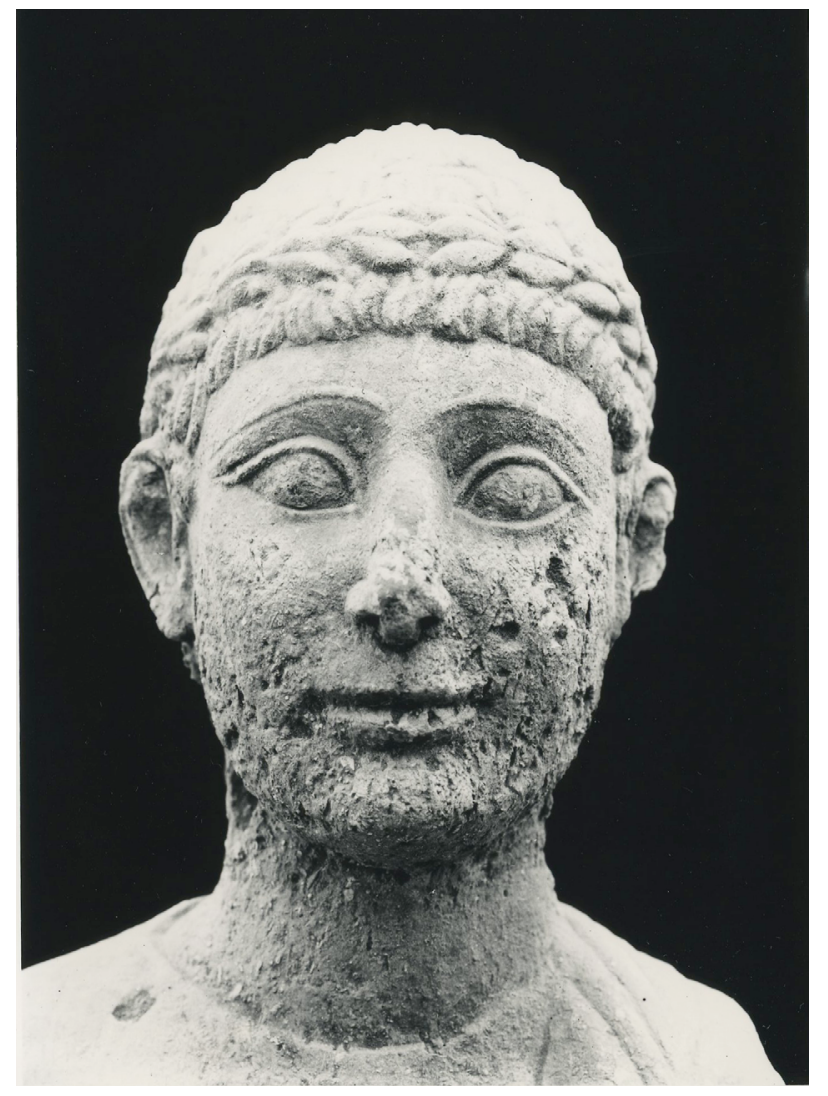

Fig. 26. Turin, Museo Egizio S. 19400. MSA-Fondo Anti inv. no. 184. Photo n. 08. Under concession by the Università degli Studi di Padova. All rights reserved.

The crate was reopened on 23 March 2017 (Cf. supra p. 9). It was found to contain an acephalous statue completely covered by protective wrap, with the exception of the feet. The protective wrap was removed, revealing the deeply damaged surface of the sculpture. Unfortunately, the left shoulder and arm are totally lost. The left side of the torso and the lower part of the right forearm are missing. The drapery of the garments and the plastically modelled outer edge of the cloak, instead, are mostly preserved. The upper left part of the back pillar is much damaged and partly missing. Modern restoration has altered the shape of the original base. The missing left part of the thick base was restored in modern times, giving it a rectangular shape.

Signs of restoration are also detectable elsewhere. Traces of a red substance are clearly visible on the left side of the back pillar. This substance was probably used to strengthen the statue. For the same reason, metal spikes were inserted into the statue. They are now visible on its back and on its left side. A fracture runs continuously from the right thigh to the left side of the back pillar. It is not visible in the

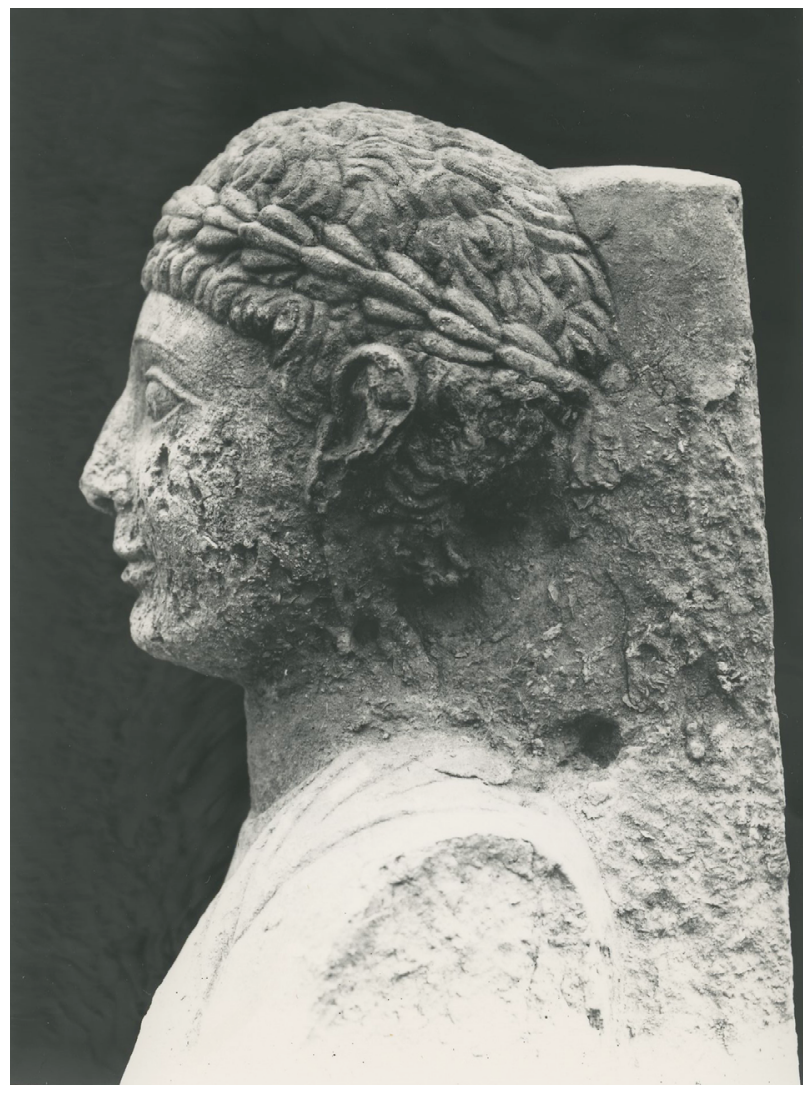

Fig. 27. Turin, Museo Egizio S. 19400, MSA-Fondo Anti inv. no. 184. Photo n. 09. Under concession by the Università degli Studi di Padova. All rights reserved.

photographs taken by Anti at the moment of the discovery, and is hence surely a result of post-excavation damage. At present we do not know when this damage was wrought.

Stylistic analysis highlights significant similarities in the rendering of the facial features between this statue and Alexandria, Graeco-Roman Museum inv. no. 22979. Both have a full and squared head, arched eyebrows, wide and almond-shaped eyes with elongated outer corners, and a long and narrow nose. Still, the two sculptures look quite different. The royal statue reproduces the physiognomy of the subject, while the non-royal one shows no realistic facial features that would allow identification of the individual portrayed. An analogous rendering of eyebrows, eyes, cheeks, and mouth is also attested in a limestone head of a sphinx coming from Medinet Madi (Fayum) (Milan, Museo Archeologico E. 0.9.40012) and commonly attributed to Ptolemy VIII. This identification, however, is far from certain ${ }^{113}$ and cannot assist in dating the statue. Nevertheless, this parallel bears witness to analogous renderings of facial features within the Fayum. 
Stylistic analysis of the lower limbs provides useful dating criteria. The modelled calves and wide feet with long toes with carved squared nails are also found in royal statue Alexandria, Graeco-Roman Museum inv. no. 22979 and in Cat. 1 (described above). It is thus likely that the three sculptures date approximately from the same period, namely the reigns of the last Ptolemies (80-30 BC ca.), thanks to the virtually certain identification of the

\section{Notes}

${ }^{1}$ We are very grateful to the director of the Museo Egizio in Turin, Christian Greco, for authorizing our study and publication of the Ptolemaic sculptures and sculptural fragments held in the museum. We would like to thank the Museo di Scienze Archeologiche e d'Arte dell'Università degli Studi di Padova, its director, Alessandra Menegazzi and her assistant Luisa Marcolin, for providing access to the photographs held in Carlo Anti's archive, and the Istituto Veneto di Scienze Lettere ed Arti and its archivist Carlo Urbani for authorizing publication of Anti's documents. We express all our gratitude to Gianfranco Adornato (Scuola Normale Superiore) and Paola Zanovello (Università degli Studi di Padova) for encouraging the collaboration between the Università degli Studi di Padova and the Scuola Normale Superiore in the study of the sculptures discovered by Carlo Anti at Tebtynis. We would like to thank all the curators of the Museo Egizio, with special thanks to Simon Connor, Alessia Fassone and Federico Poole, who helped us during our research and provided essential information. We would like to thank Andrea Meleri and Luca Toninello, Horus Project (Università degli Studi di Padova), for the discussion on the analysis of the context. We are very grateful to Luigi Prada (Lady Wallis Budge Junior Research Fellow in Egyptology, University College \& Faculty of Oriental Studies, University of Oxford), Vera Rondano (PhD student in Egyptology at the Cotsen Institute of Archaeology, UCLA) and Ian Begg (Bagnani Research Fellow, Trent University, Canada) for the time spent revising the English version of this paper, which greatly benefitted from their contributions.

${ }^{2}$ Polacco, Commemorazione; Ghedini and Biondani, Carlo Anti; Zampieri, Diari ed altri scritti; Zampieri, Diari di Carlo Anti; Zanovello and Deotto, in Zanovello and Ciampini (eds.), Egitto in Veneto.

${ }^{3}$ The sculpture is unfortunately currently inaccessible. The Graeco-Roman Museum in Alexandria has been closed to the public since 2005 for restoration and every attempt to look at sculptures held in this museum has been unsuccessful. Our study of this sculpture is hence based solely on the photographs taken by Carlo Anti at the moment of its discovery and documentation provided by scholars who were able to see the statue in person when the museum was still open to the public: Stanwick, Portraits of the Ptolemies, ruler portrayed in Alexandria, Graeco-Roman Museum inv. no. 22979 with Ptolemy XII. This hypothesis is further confirmed by the detail of the back ends of the crown carved on the sides of the back pillar, a sporadic feature typically attested in sculptures made at the end of the Ptolemaic Period, such as Berlin, Ägyptisches Museum $2271^{114}$ and Louvre E 20361. ${ }^{115}$

G.C.

pp. 123, 203, figs. 157-59; Ashton, Ptolemaic Royal Sculpture, pp. 86-87, fig. 11; Rondot, Tebtynis II, pp. 137-39, 275, figs. 103-05.

${ }^{4}$ Giulia Deotto (G.D.) authored the first section ("Discovery and archaeological context"). She has worked on Anti's archive and provided all the references to Anti's documents in the text. The author of the second and third sections ("Post-excavation history" and "Stylistic analysis") and of the catalogue entries is Giorgia Cafici (G.C.). She investigated the Tebtynis statues in Turin as part of her doctoral research - a study of Ptolemaic private portraiture - and is the author of the section about the rediscovery of the non-royal statue. The introduction and the "Final Considerations" are co-authored. This article presents an in-depth analysis of the three sculptures. However, some aspects could not be covered. At present, the possible link between all the elements found in the area of the temple (including limestone blocks, inscriptions and the reliefs carved on the walls of the vestibule) cannot be securely defined. The original position of the statues in the temple also remains uncertain. Research on these issues is still ongoing. This paper thus presents only the first results of the authors' ongoing joint research.

${ }^{5}$ Gallazzi, in Carlo Anti: giornate di studio; Gallazzi, in Casini (ed.), Cento Anni in Egitto.

${ }^{6}$ Belzoni, Viaggi in Egitto e Nubia.

${ }^{7}$ Grenfell and Hunt, The Tebtunis Papyri; Grenfell and Hunt, The Tebtunis Papyri, Part II; Grenfell and Hunt, The Tebtunis Papyri, Part III.

${ }^{8}$ Rubensohn, JDAI 20 (1905).

${ }_{9}^{9}$ Breccia, ASAE 31 (1931).

${ }^{10}$ Gallazzi, BIFAO 89 (1989); Gallazzi, Tebtynis I.

${ }^{11}$ Zanovello and Deotto, in Zanovello and Ciampini (eds.), Egitto in Veneto.

${ }^{12}$ Deotto, The University of Padova in Egypt.

${ }^{13}$ Anti, Atti Ven 89 (1929-1930).

${ }^{14}$ Bastianini and Deotto, in Zanovello and Ciampini (eds.), Antichità Egizie e Italia.

${ }^{15}$ The data about the campaign are from Anti's journals (IVSLA, Anti archive, folder 7, dossier 1, no. 1) and from some unpublished reports by him, some handwritten, others typed: "I lavori durarono nel 1931 dal 9 Gennaio al 4 Aprile, nel 1932 dal 14 Febbraio al 23 Aprile. Nella campagna del 1931 ero assistito dal Dott. Gilberto Bagnani e dall'Architetto Ing. Co. Fausto Franco..." (IVSLA, Anti archive, folder 6, dossier. 3, no. 16). 
Further information is provided by notes related to a first exhibition of the items discovered in the 1931 campaign: "Il materiale esposto raggruppa parte di quanto fu scoperto durante la sola campagna di scavo del 1931. Gli scavi sono stati eseguiti dalla Missione archeologica italiana d'Egitto, diretta dal Prof. Carlo Anti, della R. Università di Padova, con la collaborazione del Dott. Gilberto Bagnani e dell'Architetto Co. Fausto Franco" (IVSLA, Anti archive, folder 6, dossier III, no. 4).

${ }^{16}$ Bolos Ghattas, Michel Bolos' father, was a collaborator of Ernesto Schiaparelli's Italian Mission in Egypt; cf. Amin, in Moiso (ed.), Schiaparelli. He and his son also appear in many documents from the Anti archive, including photos (MSA, Anti archive, no. 211, photo 001) and reports (MSA, Anti archive, n. 129). The workers and Bolos sent letters and reports to Anti, preserved in IVSLA, Anti archive, folder 6, dossier VIII, a folder dedicated to the Egyptian personnel, or in IVSLA, Anti archive, folder 9.

${ }^{17}$ The plan, now preserved in the Museo di Scienze Archeologiche e d'Arte dell'Università degli Studi di Padova, was studied by the Horus Project, an innovative research project involving students of the Università degli Studi Padova, supervised by Paola Zanovello and Giulia Deotto. The team also includes professors, researchers and technicians of the Dipartimento dei Beni Culturali (dBC) and the Centro di Ateneo di Studi e Attività Spaziali "Giuseppe Colombo" (CISAS) of the Università degli Studi di Padova. A first publication and a detailed study of the map, carried out by the Horus project's team and Alessandra Menegazzi, are forthcoming: Deotto et al. (eds.), Horus project.

${ }^{18}$ IVSLA, Anti archive, folder 6, dossier 2, no. 16.

${ }^{19}$ Anti, Aegyptus 11 (1931); Anti, BASM 2 (1931); Anti, in Atti del Regio Istituto di Scienze Lettere ed Arti, XCI, 2 (1931-1932).

${ }^{20}$ IVSLA, Anti archive, folder 6, dossier 2, no. 16.

${ }^{21}$ IVSLA, Anti archive, folder 7, dossier 1, no. 1. Anti's journal together with Anti's unpublished study of the site will be edited by Claudio Gallazzi, Paola Zanovello and Giulia Deotto with a selection of photos made in collaboration with Alessandra Menegazzi, in the framework of a cooperation between the Università degli Studi di Padova, the Istituto Veneto, the Museo di Scienze Archeologiche e d'Arte dell'Università degli Studi di Padova and the Tebtynis team (Università degli Studi di Milano and IFAO).

${ }_{22}$ Anti, Il Regio Museo Archeologico di Venezia.

${ }^{23}$ Anti, Dedalo 1 (1921); Anti, Art of America 12 (19231924); Anti, MonAnt 29 (1923); Anti, Università di Padova; Anti, Teatri greci arcaici and Anti, Guida per il visitatore del Teatro Antico, to cite only a few examples.

${ }^{24} \mathrm{Cf}$. here, the section "Stylistic Analysis".

25 The feet of the royal statue are visible in MSA, Anti archive, inv. no. 186, photo 001, near the east basement. The second fragment of the body is visible in MSA, Anti archive, inv. no. Box1Sparsa, no. 064. "Nell'angolo formato dal parapetto orientale e dalla facciata del tempio sud si trova in posto la parte inferiore di una statua virile stante di tipo egizio. Tra i piedi e il muro del parapetto giaceva incastrato e rovesciato il pezzo dalle ginocchia alla cintola, pezzo che certo appartiene al pezzo in situ anzi sembra connettere... Nell'angolo formato dal pilone occidentale del tempio e il muro di cinta (?), sul lato nord a m. 1.10 dal ciglio superiore del muro stesso (A), si trova, fra il terriccio, una testa di faraone tolemaico, ornata del claft e dell'ureo...A m. 3 dallo spigolo SE del pilone ovest e m. 2 dal ciglio anteriore del pilone (B) si trova un busto faraonico.". (IVSLA, Anti archive, folder 7, dossier 1, no. 1). The discovery of the inscription related to Ptolemy XII, usually linked by scholars to this statue, and the style of the sculpture are discussed here on pp. 7 and 11-13.

${ }^{26}$ La R. missione archeologica italiana di Egitto, https://patrimonio.archivioluce.com/luce-web/detail/ IL3000051873/1/scavi-della-missione-archeologia-italiana-egitto-gennaio-aprile-1931 (accessed May 30, 2017); it appears, together with the two other statues, at about 4'20".

${ }^{27}$ IVSLA, Anti archive, folder 8, dossier 2, no. 1.

${ }^{28}$ IVSLA, Anti archive, folder 6, dossier VII - VIII, no. 68.

${ }^{29}$ Adriani replied that it was 2.37 meters high without the 0.25 meter high plinth (IVSLA, Anti archive, folder 7, dossier 2, no. 36). The dimensions indicated by Stanwick are H: $211.4 \mathrm{~cm}$, Base H: $24 \mathrm{~cm}, \mathrm{~W}: 54 \mathrm{~cm}$, D: $78 \mathrm{~cm}$ (Stanwick, Portraits of the Ptolemies, p. 123). 30 “TEMPIO SUD. Si raggiunge l'angolo SE della sala a rilievi. Questi, sulla parete sud, sono bene conservati, come superficie della pietra. Nell'angolo la parte inferiore di una statua di media grandezza. Procedendo ad isolare il mucchio di blocchi centrali, dal lato est, si notano sul pavimento numerose tracce di cenere e carboni...Il torso faraonico viene trovato sul lato ovest, a metri 1 da terra, coricato entro la sabbia." (IVSLA, Anti archive, folder 7, dossier 1, no. 1). It is reported also in IVSLA, Anti archive, folder 6, dossier III, no. 4: "n. inv. 313 - Statuetta di Faraone. Calcare. Alt. M. 2,50 (?). Fu trovata in pezzi nel vestibolo a rilievi del Santuario, meno la testa raccolta nell'interno del santuario stesso. La base con i piedi giaceva nell'angolo SO del vestibolo forse ancora al posto originale. La testa è così consunta non per uno sfregio intenzionale, ma per aver giaciuto molti secoli in uno strato di terriccio, ricco di sostanze corrosive. È il tipo classico del Faraone: i fianchi ravvolti dallo shendit, i capelli coperti dal klaft, il capo sormontato dalla doppia corona dell'alto e del basso Egitto. Lavoro abbastanza curato, probabilmente di epoca romana. Manca qualsiasi indizio per attribuirgli un nome." In a list of items, it is mentioned as "Statuette of pharaoh in four pieces, h. 1.30 m” (IVSLA, Anti archive, folder 8, dossier 2, no. 1). In this paper, and only in this case, it is mentioned that it was broken in four fragments. Some photographs of the discovery are preserved in the archive, such as MSA, Anti archive, no. 281 photo 009. For a detailed stylistic analysis, see here, "Cat. 1". 31 "Si concentra tutta la mano d'opera nell'angolo NO del recinto del grande tempio. Sul lato ovest della muraglia perimetrale, a m. dall'angolo NO viene in luce una porta a stipiti di pietra. Nell'ambiente d'angolo, trasformato in epoca tarda, come il resto, in stalla, si raccoglie fra le immondezze la testa della statuetta 
di faraone ricuperata nel cortile a rilievi, e un grande timbro in legno lungo 0.525." (IVSLA, Anti archive, folder 7, dossier 1, no. 1). The stamp (timbro) was documented with photographs and drawings. It came from the oven, identified as a bakery by Anti. More precisely, it was inside one of the rooms of the building, numbered as 12 in Franco's plan.

${ }^{32}$ Anti wrote: "Fu trovata in pezzi nel vestibolo a rilievi del Santuario, meno la testa raccolta nell'interno del santuario stesso. La base con i piedi giaceva nell'angolo SO del vestibolo forse ancora al posto originale. La testa è così consunta non per uno sfregio intenzionale, ma per aver giaciuto per molti secoli in uno strato di terriccio ricco di sostanze corrosive...” (IVSLA, Anti archive, folder 6, dossier 3, no. 4) and “...Nell'ambiente d'angolo, trasformato in epoca tarda, come il resto, in stalla, si raccoglie fra le immondezze la testa della statuetta di faraone ricuperata nel cortile a rilievi..." (IVSLA, Anti archive, folder 7, dossier 1, no. 1).

${ }^{33}$ IVSLA, Anti archive, folder 8, dossier 2, no. 1.

${ }^{34}$ In the 1931 report for the Service des Antiquités de l’Égypte Anti writes: "Le portale est flanqué par une statue pharaonique et par un lion couché. La première salle, de $13 \mathrm{~m}$. sur 13, a les parois couvertes des reliefs en creux. Dans la salle on a trouvé aussi la statue d'un prêtre." (IVSLA, Anti archive, folder 6, dossier V, no. 18). Moreover, he reports in his notes: "Nell'interno del tempio sud si raccoglie un torsetto di figura paludata stante...” and “...Nell'interno del tempio Sud, nella parte est a circa m. 2,50 dal muro nord e m. 2,50 circa dalla linea dello stipite, tra la sabbia, a circa m 1,25 dal pavimento si trova la parte superiore di una statua di sacerdote, di epoca romana, che completa un frammento trovato vari giorni prima in uno strato ancora più superficiale. Calcare scadente, non omogeneo, con molti detriti di conchiglie. La statua è in 3 pezzi..." (IVSLA, Anti archive, folder 7, dossier 1, no.1).

${ }^{35}$ Anti referred to it as a priest on several occasions, e.g., in his description for the exhibition in Rome: "n. inv. 314 - Statuetta di sacerdote. Calcare. Alt. M. 1,30. Venne trovata nel vestibolo a rilievi del Santuario. La scultura è costruita nello schema egiziano tradizionale, la testa è coronata di mirto e il corpo è avvolto nella tunica e nello scialle frangiato che era caratteristico dei sacerdoti. Lavoro della fine dell'epoca tolemaica." (IVSLA, Anti archive, folder 6, dossier III, no. 4). For a detailed stylistic analysis of this sculpture, together with the other two statues, see here, «Cat. 2 ».

${ }^{36}$ IVSLA, Anti archive, folder 8, dossier 2, no. 1.

${ }^{37}$ The statues also appear together in the abovementioned documentary film, La R. missione archeologica italiana di Egitto, https://patrimonio.archivioluce. com/luce-web/detail/IL3000051873/1/scavi-della-missione-archeologia-italiana-egitto-gennaio-aprile-1931 (accessed May 30, 2017), at about 4'20”. Anti continued to mention them as a group after the excavation, as, for example, in a report written in Rome on the 28th April, 1931: "Parmi le sculptures, outre le bas-reliefs des parois des vestibule, on doit signaler trois statues d'art ptolémaïque et romaine dont l'une est colossale..." (MSA, Anti archive, folder 1, no. 7).

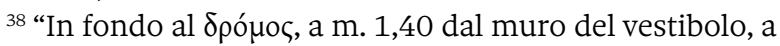
destra e a sinistra del portale di questo, sono due basi, quella di est in calcare duro e scuro, l'altra in calcare bianco tenero. Sono ambedue in connessione con il lastricato più antico, anteriori all'attuale e alla


6, dossier 3, no. 16). The east basement is visible in MSA, Anti archive, no. inv. 186, photo 001.

${ }^{39}$ The east block is depicted in Franco's map as a rectangle of size $0.80 \times 1.35 \mathrm{~m}$; while the west pedestal sizes m $0.94 \times 1.24$ (measurements calculated on the basis of the scale of the map by Andrea Meleri, Horus Project, Università degli Studi di Padova). These measurements quite closely match those reported by Anti (IVSLA, Anti archive, folder 7, dossier 1, no. 1. Anti however, gives a width of $1 \mathrm{~m}$ for the west pedestal instead of $0.94 \mathrm{~m}$ ).

${ }^{40}$ Cf. supra and infra, nn. 25 and 42.

41 "Nell'angolo tra la porta del tempio e il muro ovest della via processionale, nel piccolo spazio tra la figura di leone e il detto parapetto erano due blocchi di pietra, che evidentemente erano stati gettati là alla rinfusa. Quello maggiormente nell'angolo è il parallelepipedo con un dente che sporge ad una delle estremità." (IVSLA, Anti archive, folder 7, dossier 1, no. 1). The inscription can be identified on the basis of information provided in Anti's journal, which includes a drawing of the inscribed face of the block and some remarks on its material “...data anche la qualità del calcare, il blocco non può provenire dalla facciata del tempio, ma appartiene con ogni probabilità alla base che sporge dal parapetto vicino all'angolo dove è stato trovato il blocco." (IVSLA, Anti archive, folder 7, dossier 1, no. 1). The inscription is also documented by photographs (MSA, Anti archive, no. inv. 289, photo 001).

42 "Presso la base est che è composta di blocchi molto ben squadrati, venne trovata in pezzi ma completa una grande statua faraonica, alta m. [sic.]. Il viso è veristico, ma certo non è un imperatore romano e però deve trattarsi di un Tolomeo. Fra i blocchi crollati intorno alla base ovest la quale presenta tecnica analoga a quella degli altari, venne trovato un blocco di materiale identico e quindi certo appartenente con la seguente iscrizione [sic.]. Data la diversità di materiale e di lavoro delle due basi e le loro rispettive caratteristiche è da ritenere che la statua non rappresenti Tolomeo Neo-Dioniso, ma un Tolomeo più antico." (IVSLA, Anti archive, folder 7, dossier 3, no. 4). The inscription is also documented by photographs (MSA, Anti archive, no. inv. 289, photo. 001).

${ }^{43}$ The block with the inscription is $0.35 \mathrm{~m}$ in height, $0.69 \mathrm{~m}$ wide, 0.27-0.34 m deep (IVSLA, Anti archive, folder 7 , dossier 1, no. 1).

44 "Le facce B e C erano viste, date le lavorazioni e dato che su esse si intravvedono dei graffiti, invece il lato posteriore era murato perché restano molte tracce di gesso e la lavorazione è diversa. Dato questo e data anche la qualità del calcare, il blocco non può 
provenire dalla facciata del tempio, ma appartiene con ogni probabilità alla base che sporge dal parapetto vicino all'angolo dove è stato trovato il blocco." (IVSLA, Anti archive, folder 7, dossier 1, no. 1).

${ }^{45}$ The width of the front of the block with the inscription was $0.69 \mathrm{~m}$, that of the pedestal $0.94 \mathrm{~m}$. The inscription on the block is $59.5 \mathrm{~cm}$ wide. (IVSLA, Anti archive, folder 7, dossier 1, no. 1).

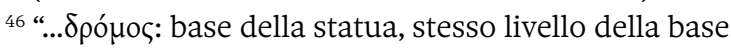
dell'iscrizione? (se l'iscrizione appartiene alla base). Base est completa? Dunque statua? Iscrizione appartiene alla base ovest? Materiale dunque non in relazione con la statua. Base più alta? Statua più piccola? (l'altra?) Le due basi stesso livello? Stessa tecnica? Veramente simmetriche? Cfr. elementi architettonici del cortile con altari" (IVSLA, Anti archive, folder 7 , dossier 2, no. 22).

${ }^{47}$ Cf. supra nn. 43 and 45. "Presso la base est che è composta di blocchi molto ben squadrati, venne trovata in pezzi ma completa una grande statua faraonica, alta $\mathrm{m}$. [sic.]. Il viso è veristico, ma certo non è un imperatore romano e però deve trattarsi di un Tolomeo. Fra i blocchi crollati intorno alla base ovest la quale presenta tecnica analoga a quella degli altari, venne trovato un blocco di materiale identico e quindi certo appartenente con la seguente iscrizione [sic.]. Data la diversità di materiale e di lavoro delle due basi e le loro rispettive caratteristiche è da ritenere che la statua non rappresenti Tolomeo Neo-Dioniso, ma un Tolomeo più antico." (IVSLA, Anti archive, folder 7, dossier 3, no. 4). The inscription was also documented by photographs (MSA, Anti archive, no. inv. 289, photo.001).

${ }^{48}$ Cf. pp. 12-13.

${ }^{49}$ Cf. supra nn. 30-32.

${ }^{50}$ Cf. infra. n. 91.

${ }^{51}$ One royal statue remained in Egypt (Alexandria, Graeco-Roman Museum inv. no. 22979) while the other two were sent to Italy. Cf. pp. 4-6.

${ }^{52}$ Private letter sent by Gilbert Bagnani to Carlo Anti: “5/6/32/VI, via Pompeo Magno/ Roma/Caro Professore, / le invio a parte le fotografie dei capitelli che spero la soddisferanno. Sono state difficilissime a prendersi in quanto non si trovavano a via Gaeta ma nei magazzini a Villa Giulia. Non sono riuscito a rintracciare gli altri frammenti della statua. / Il Calza mi dice che la mostra sarà certo prorogata oltre la fine di questo mese. Visto però che gli arredi non devono tornare a Pennsylvania gli rimarrebbe una vetrina disponibile e mi domanda se sarebbe il caso di far sostituire gli smalti etc./ Nel caso che lei è contento penserei io a mettere in ordine la vetrina. Mi pare anche che sarebbe una buona occasione per far venire a Roma il papiro che potrebbe venire esposto./ Alla fine della mostra penso che sarebbe bene riportare tutto alle Terme e farlo ivi restaurare./ La statua del sacerdote ha ancora tutte le incrostazioni di sale ed è pure stata danneggiata./ Uno dei capitelli con un bagno d'acqua prolungato potrebbe venir completamente liberato dalle incrostazioni che ne deturpano il collarino./ Mi accorgo che ancora non ho letto abbastanza per poter affrontare il papiro e ho passato il mese traducendo a più non posso testi geroglifici. La mancanza di libri è un disastro! Perdo ore girando le biblioteche e constatando la mancanza di tutto! / Maria Rosa mi ha telefonato dicendomi che era impressionatissima di non aver ricevuto sue nuove e Marconi idem./ Le accludo, dulcis in fundo, il conto. Spero che avrà ricevuto gli ostraca. Non ho mandato la cassetta per Faenza poiché non sono sicuro della sabbia e si potrebbe fare con più comodo alle Terme ma se vuole posso provvedere. / Mia moglie pure lei manda tanti saluti/ sempre suo/ Gilberto Bagnani/ P.S. Non ho ancora ricevuto l'Engelbach [sic]" (IVSLA, Anti archive, folder 9, no. 25). The same exhibition was also mentioned in a letter written by Carlo Anti to Guido Calza on September 20, 1931: "Riassumendo il materiale prescelto comprende: 1 ) due statuette in calcare..." (IVSLA, Anti archive, folder 9, no. 155) in 1931.

${ }^{53}$ Ministero dell'Educazione Nazionale (ed.), Mostra d'arte antica.

${ }^{54}$ Ministero dell'Educazione Nazionale (ed.), Mostra d'arte antica, p. 9. On the intersection between political ideology and the celebration of antiquity at the beginning of the 19th century see also Barbanera, in Barbanera (ed.), L'archeologia degli italiani; Barbanera, in Schlanger (ed.), Archives, ancestors, practices, and Adornato, Osservatorio Mostre e Musei.

${ }^{55}$ Ministero dell'Educazione Nazionale (ed.), Mostra d'arte antica, pp. 7-9.

${ }^{56}$ Ministero dell'Educazione Nazionale (ed.), Mostra d'arte antica, p. 59: “1. Statuetta di Faraone da Tebtunis (Fayoum). Scavi della Missione Archeologica Italiana in Egitto, diretta dal Prof. Carlo Anti, 1930-1931”. 2. "Statuetta di Sacerdote da Tebtunis (Fayoum). Scavi della Missione Archeologica Italiana in Egitto, diretta dal Prof. Carlo Anti, 1930-1931.” 3-4. “Due capitelli copti da Tebtunis (Fayoum). Scavi della Missione Archeologica Italiana in Egitto, diretta dal Prof. Carlo Anti, 1930-1931."

${ }^{57}$ Cf. supra n. 35. On draped statues, cf. Bianchi, The Striding Draped Male Figure and Warda, Egyptian Draped Male Figures.

${ }^{58}$ Valtz, in Sesto congresso internazionale di Egittologia: Atti, p. 626.

${ }^{59}$ Rondot, Tebtynis II, p. 139.

${ }^{60}$ Rondot, Tebtynis II, p. 139, n. 112.

${ }^{61}$ Rondot, Tebtynis II, p. 139.

${ }^{62}$ Cafici, EVO 39 (2016).

${ }^{63}$ Cf. here “Cat. 1”, pp. 14-16.

${ }^{64}$ Turin, Museo Egizio S. 19400/01 RCGE 62231.

${ }^{65}$ Conservative action on Turin, Museo Egizio S. 19400 and Turin, Museo Egizio S. 19400/01 is envisaged in the near future. The two sculptural fragments will be restored and joined.

${ }^{66}$ This detail is not clearly visible in the photographs from the Anti archive. It is however barely visible in Stanwick, Portraits of the Ptolemies, p. 203, fig. 158 and is mentioned by Sally-Ann Ashton, who had direct access to the statue: Ashton, Ptolemaic Royal Sculpture, pp. 86-87.

${ }^{67}$ Hölbl, History, pp. 222-27, 229-30.

${ }^{68}$ Bothmer, Egyptian Sculpture of the Late Period, pp. 171-72; Bastianini and Gallazzi, QTNAC 18 (1989), 
p. 205; Stanwick, JARCE 29 (1992), pp. 138-39; Ashton, Ptolemaic Royal Sculpture, p. 86; Stanwick, Portraits of the Ptolemies, pp. 60, 123. Only Klaus Parlasca identified the ruler as Ptolemy $\mathrm{X}$ on the basis of physiognomic comparison with stone portraits attributed to this king (Louvre E 8061, Wien, Kunsthistorisches Museum ÄOS 26, Munchen, Staatliche Museum Ägyptischer Kunst inv. 5339, Geneva, Musée d'art et d'histoire inv. 20240). Parlasca, in Maehler and Strocka (eds.), Das Ptolemäische Ägypten, p. 26. This identification however is unconvincing.

${ }^{69}$ For examples, cf. Poole, Catalogue of the Greek Coins, pl. 29 and Svoronos, Die Münzen der Ptolemäer, IV, p 1. 61, nos. 22-23 (designated as Ptolemy XIII).

${ }^{70}$ Boston, Museum of Fine Arts inv. no. 53.456, http:// www.mfa.org/collections/object/drachm-of-kingdom-of-egypt-with-bust-of-ptolemy-xiii-3241 (accessed September 5, 2017).

${ }^{71}$ Kyrieleis, Bildnisse, pp. 75-76, pl. 68, 1-2, Smith, Hellenistic Royal Portraits, p. 97, pl. 75.20; Hazzard, Ptolemaic Coins, pp. 12, 119, fig. 152; and Stanwick, Portraits of the Ptolemies, pp. 60, 225 fig. 240.

${ }^{72}$ London, British Museum 1987,0649.520, https:// www.britishmuseum.org/research/collection_online/ collection_object_details/collection_image_gallery. aspx?assetId $=683473001 \&$ objectId $=1267116$ \&partId=1\#more-views (accessed September 5, 2017). The identity of the sovereign depicted in this portrait type is still debated by scholars. The portrait has been alternatively identified with Ptolemy I or Ptolemy XII. Although its identification remains uncertain, the coin is surely dated to the reign of Ptolemy XII by the iconography and the caption on its reverse (ПTO $\Lambda$ EMAIOY BA $\Sigma I \Lambda \mathrm{E} \Omega \Sigma$, eagle standing left on thunderbolt, palm branch over shoulder, LKH over headdress of Isis in left field, $\Pi$ A in right field. cf. Poole, Catalogue of the Greek Coins, p. 116).

${ }^{73}$ See Stanwick, Portraits of the Ptolemies, pp. 60, 122 Cat. E1, 202, figs. 153-54, only to cite the most recent study.

${ }^{74}$ See at least Kyrieleis, Bildnisse, pp. 76-77, cat. I, 1, p. 178, pl. 69, 1-3 and Stanwick, Portraits of the Ptolemies, pp. 60, 234, figs. 274-275.

${ }^{75}$ Cf. supra n. 42.

${ }^{76}$ Bastianini and Gallazzi, QTNAC 18 (1989), p. 204. Anti, on the contrary, does not link the inscribed block with the statue now in Alexandria in his notes. Cf. supra n. 42. Both hypotheses are possible but for the time being none of them is provable. Further researches on the sculptural fragments, pedestals and the inscribed block are currently underway in order to better understand their original setting.

${ }^{77}$ Bastianini and Gallazzi, QTNAC 18 (1989), pp. 20109, SEG 39-1705.

${ }^{78}$ The name of the honorand often appears in the accusative. See Guarducci, Epigrafia greca II, p. 126, 147-148; Bastianini and Gallazzi, QTNAC 18 (1989), p. 203; Ma, Statues, pp. 45-63.

${ }^{79}$ Bastianini and Gallazzi, QTNAC 18 (1989), pp. 203-04; Hölbl, History, p. 229.

${ }^{80}$ Bastianini and Gallazzi, QTNAC 18 (1989), p. 201;
Stanwick, Portraits of the Ptolemies, p. 123.

${ }^{81}$ Bastianini and Gallazzi, QTNAC 18 (1989), p. 201. With regard to the items from Tebtynis, see Davoli, L'archeologia urbana nel Fayyum. See Arslan and Tiradritti, L'Egitto a Milano; regarding the items held at the Università degli Studi di Padova and their relation with Anti archive, see: Zanovello in Zanovello et al. (eds.), Studi Egittologici in Veneto, pp. 67-68; and Deotto, in Zanovello et al. (eds.), Studi Egittologici in Veneto, pp. 68-71. Most of the items sent by Anti to Italy are now kept in Turin. The reconstruction of their provenance in the context of Anti's excavations and their modern history is part of a joint project of the Università degli Studi di Padova and the Museo Egizio in Turin.

82 Bastianini and Gallazzi, QTNAC 18 (1989).

${ }^{83}$ Cf. supra n. 42.

${ }^{84}$ Cf. supra nn. 38-42.

${ }^{85} \mathrm{Cf}$. supra nn. 42 and 47 . However, one should keep in mind that different varieties of limestone in one and the same monument are attested in Egypt. For example, six different types of limestone were identified in the masonry at Siwa's Agurmi temple, built during the reign of the pharaoh Amasis (Bruhn and Lembke, Ammoniaca I, p. 63).

${ }^{86}$ Cf. supra n. 39.

${ }^{87}$ Cf. supra nn. 29 and 39. The east block was depicted as a rectangle measuring $0.80 \times 1.35 \mathrm{~m}$, while the measurements of the west pedestal are m 0.94x1.24. The base of the statue Alexandria, Graeco-Roman Museum inv. no. 22979 has the following measurements: H: $24 \mathrm{~cm}$, W: $54 \mathrm{~cm}, \mathrm{D}: 78 \mathrm{~cm}$ (Stanwick, Portraits of the Ptolemies, p. 123). The block with the inscription is $0.35 \mathrm{~m}$ in height, $0.69 \mathrm{~m}$ in width and $0.27 \times 0.34 \mathrm{~m}$ in depth. The inscription inside the block is W: $59,5 \mathrm{~cm}$. Cf. supra nn. 43-45.

${ }^{88}$ Malek, in Assmann et al. (eds.), Thebanische Beamtennekropolen, pp. 43-45 and Malek, in Strudwick and Taylor (eds.), The Theban Necropolis, pp. 229-43.

${ }^{89}$ Malek, in Strudwick and Taylor (eds.), The Theban Necropolis, p. 229.

${ }^{90}$ The study of archives, photographic material and original artefacts is currently widespread in Egyptology. On this topic see also Piacentini, Gli archivi egittologici; Moiso (ed.), Schiaparelli; Piacentini, Victor Loret in Egypt; Piacentini and Orsenigo, Egyptian archives; Piacentini, Egypt and the pharaohs; Quirke, Hidden Hands; Moiso, in Consonni et al. (eds.) L'Egitto, pp. 37-54; Moiso, in Consonni et al. (eds.), L'Egitto, pp. 179-86; Sbriglio, "Gli scavi Schiaparelli“; Sbriglio and Ugliano in Pinarello et al. (eds.), Current Research in Egyptology 2014, pp. 278-93; Ugliano, "La collezione predinastica”; Riggs, History of Photography 40 (2016), pp. 267-82; Riggs, Archival Science 17/2 (2017), 12550; Riggs, HistSc 2016 (epub ahead of print). https:// doi.org/10.1177/0073275316676282 (accessed September 5, 2017), only to cite some examples.

${ }^{91}$ At present, the relationship between all the sculptural and decorative elements found in the area of the temple (including limestone blocks, inscriptions 
and reliefs) cannot be surely defined, but we hope that further investigation of the archival material in Padua will shed further light on this issue. For example, the size and the findspots of Turin, Museo Egizio S. 18176 and Turin, Museo Egizio S. $19400+$ S. 19400/01 might suggest a link between these sculptures. Turin, Museo Egizio S. 18176 is $164 \mathrm{~cm}$ high and Turin, Museo Egizio S. $19400+$ S. 19400/01 is about $134 \mathrm{~cm}$ high. However, the height of the royal statue without the double crown is $140 \mathrm{~cm}$. The hands of the two sculptures are $7 \mathrm{~cm}$ in width and their feet $20 \mathrm{~cm}$ in height. The fragments belonging to these two statues were all discovered inside the vestibule with the exception of the head of the royal statue, found in Room 12 in a layer of rubbish (Cf. supra nn. 30-32). These details thus seem to confirm that the two statues were probably set up in the same location approximately in the same period. At present, however, their link cannot be surely defined and this hypothesis cannot be proved for the time being.

${ }^{92}$ Anti reports a height of $2.50 \mathrm{~m}$ in his notes (Cf. supra n. 30). However, the Italian archaeologist himself added a question mark in brackets. Indeed, the height given by Anti does not correspond to that the royal statue now held in Turin, but with that of the one in Alexandria, and is thus probably an oversight.

${ }^{93}$ Not including exhibition catalogues where the statue is only shortly described, but without adding to our knowledge about it.

${ }^{94}$ Information obtained from the Museo Egizio's internal database.

${ }^{95}$ Rondot, Tebtynis II, p. 136.

${ }^{96}$ For example, in statue Cairo, Egyptian Museum CG 14 (Borchardt, Statuen und Statuetten, p. 14, pl. 4) king Chephren wears a nemes characterized by a plain upper section and a banded lower section.

${ }^{97}$ For example, the statues of Ramses II that decorate the façade of the Great Temple at Abu Simbel wear a banded nemes and a double crown.

${ }^{98}$ Stanwick, Portraits of the Ptolemies. pp. 55-56, 99-100, 159, fig. 8 ; Brissaud and Zivie-Coche, Tanis, pp. 110,171 , pl. 25 . Stanwick dates the sculpture to the third century BC.

${ }^{99}$ The sphinx head comes from Medinet Madi. Milan, Museo Archeologico E. 0.9.40012. Smith, Hellenistic Royal Portraits, pp, 87, 97, 171, cat. 82, pl. 50; Stanwick, Portraits of the Ptolemies, pp. 112, 180, fig. 83; Brophy, Royal Statues in Egypt p. 120, cat. 43. Stanwick and Brophy attribute the head to Ptolemy VIII, while Smith dates the sculpture to the second or first century BC.

${ }^{100}$ For a definition of the tripartite torso, see Bothmer, Egyptian Sculpture of the Late Period, pl. XXXV.

${ }^{101}$ Rondot, Tebtynis II, p. 136.

${ }^{102}$ Cf. Stanwick, Portraits of the Ptolemies, pp. 114 cat. C12, 184, fig. 98.

${ }^{103}$ Stanwick identifies the ruler portrayed as Ptolemy IX, while Jucker and Russmann propose an identification with Ptolemy IV. Cf. Jucker, AntKunst 18 (1975) p. 23, pl. 9 1-2; Russmann, Eternal Egypt, pp. 257-58 and Stanwick, Portraits of the Ptolemies, pp. 120 cat. D17,
198, fig. 141. See also: https://www.britishmuseum. org/collection/object/Y_EA1209 (accessed December 9, 2020).

${ }^{104}$ Cf. Stanwick, Portraits of the Ptolemies, p. 204, fig. 163.

105 The height of the statue is given by Carlo Anti in IVSLA, Anti archive, folder 7, dossier 1, no. 1. Cf. supra n. 35 and infra n. 109. Turin, Museo Egizio S. $19400+$ S. $19400 / 01$ is about $134 \mathrm{~cm}$ high (cf. supra n. 91). The height given by Vincent Rondot is about $120 \mathrm{~cm}$ (Rondot, Tebtynis II, p. 139). Since he regarded the body to be unaccounted for, he presumably estimated this height from Anti's photograph (see Fig. 1 in this article, above), by comparing it with the other two sculptures, whose measurements he knew. ${ }^{106}$ Cf. supra nn. 34-35.

${ }^{107}$ Typically the right hand held down along the body would be clasped around a cylindrical object, but this is not visible either in the photographs nor in the sculpture in its present state.

${ }^{108}$ There are not many attestations of this kind of crown. The other known examples are statue Cairo, Egyptian Museum JE 37520, found in the Karnak cachette (IFAO. Cachette de Karnak, http://www.ifao.egnet. net/bases/cachette/\#galerie [accessed September 5, 2017]) and another sculpture discovered at Tebtynis, Cairo, Egyptian Museum JE 65424 A (Rondot, Tebtynis II, p. 278, figs. 112-15). Back ends of crowns carved on the sides of the back pillar are attested in some sculptures made at the end of the Ptolemaic Period. Cf. here, p. 20.

${ }^{109}$ Cf. here, Cat. 1. Carlo Anti also noticed traces of colour on the statue: "Calcare scadente, non omogeneo, con molti detriti di conchiglie... Altezza m. 1.32 (circa perché la statua non è ancora ricomposta)... Colori: tunica, frange, scialle, mano sinistra, frammenti di capelli e orecchi, manone (le divisioni tra dito e dito della sinistra mancante con un segno marrone più scuro); labbra e narici: rosse; iridi: nere." IVSLA, Anti archive, folder 7 , dossier 1, no. 1 . These traces of colour are not currently visible to the naked eye.

${ }^{110}$ On draped garments see Bianchi, The Striding Draped Male Figure and Warda, Egyptian Draped Male Figures.

${ }^{111}$ Fringes are usually widely attested in this type of garment during the Ptolemaic Period. The skirt is poorly preserved and the photographs did not allow us to verify the presence or absence of fringes. If these were carved they would be rendered differently from the mantle.

${ }^{112}$ Further conservation is envisaged in the near future. I am grateful to the registrar Marco Rossani and Giulia Gregori for providing me with a copy of the restoration report by Gian Luigi Nicola.

${ }^{113}$ Vogliano, Un'impresa archeologica Milanese pl. 19 and Stanwick, Portraits of the Ptolemies, p. 112 propose an identification with Ptolemy VIII. Smith, Hellenistic Royal Portraits, p. 97 instead proposes a date in the second or first century BC.

${ }^{114}$ Lembke and Vittmann, JBM 42 (2000), p. 10, fig. 3.

${ }^{115}$ Perdu, Les statues privées, pp. 382, 385, figs. 4-5. 


\section{Bibliography}

Adornato, Gianfranco, "Mostre di archeologia in Italia. Storia, sviluppi, tendenze (dal 1880 a oggi)",

Scuola Normale Superiore di Pisa. Osservatorio Mostre e Musei. Studi e ricerche, 2007, pp. 12-18.

Amin, Francis, “Bolos Ghattas”, in: Beppe Moiso (ed.), Ernesto Schiaparelli e la tomba di Kha, Torino 2008, p. 284.

Anti, Carlo, “Scultura negra”, Dedalo 1 (1921), pp. 592-621.

Anti, Carlo, “The Sculpture of the African Negroes”, Art of America 12 (1923-1924), pp. 14-26.

Anti, Carlo, "Esplorazioni archeologiche nella Licia e nella Panfilia ", MonAnt 29 (1923), pp. 657-786.

Anti, Carlo, "Archeologia d'Oltremare II, Campagna 1929”, Atti Ven. 89 (1929-1930), pp. 731-56.

Anti, Carlo, Il Regio Museo Archeologico nel Palazzo Reale di Venezia, Roma 1930.

Anti, Carlo, "Gli scavi della Missione Archeologica Italiana a Umm el Breighât (Tebtunis)”, Aegyptus 11 (1931), pp. 389-91.

Anti, Carlo, "Gli scavi della Missione Archeologica Italiana a Umm el Breighât (Tebtunis)”, BASM 2 (1931), pp. 23-24.

Anti, Carlo, "Archeologia d'Oltremare IV, Campagna 1931", in: Atti del Regio Istituto di Scienze Lettere ed Arti, XCI, 2 (1931-1932), pp. 1171-72.

Anti, Carlo, Università di Padova - Descrizione sommaria delle sale accademiche, Padova 1942.

Anti, Carlo, Teatri greci arcaici: da Minosse a Pericle, Padova 1947.

Anti, Carlo, Guida per il visitatore del Teatro Antico di Siracusa, Firenze 1948.

Arslan, Ermanno and Francesco Tiradritti, L'Egitto a Milano: nuove acquisizioni e restauri, Milano 1991.

Ashton, Sally-Ann, Ptolemaic Royal Sculpture from Egypt: The Interaction between Greek and Egyptian Traditions, Oxford 2001.

Barbanera, Marcello, “La tradizione del passato e l'origine della crisi: l'archeologia tra le due guerre (19201945)", in Barbanera (ed.), L'archeologia degli italiani: storia, metodi e orientamenti dell'archeologia classica in Italia, Roma 1998, pp. 119-54.

Barbanera, Marcello, "The Impossible Museum. Exhibitions of Archaeology as Reflections of Contemporary Ideologies", in: Nathan Schlanger (ed.), Archives, Ancestors, Practices: Archaeology in the Light of its History, Oxford 2008, pp. 165-77.

Bastianini, Guido and Giulia Deotto, "Carlo Anti e Girolamo Vitelli”, in: Paola Zanovello and Emanuele Marcello Ciampini (eds.), Antichità Egizie e Italia: prospettive di ricerca e indagini sul campo. Atti del III Convegno di Egittologia: ricerche sull'antico Egitto in Italia (Venezia 14-15 settembre 2012), Venezia 2014, pp. 47-51.

Bastianini, Guido and Claudio Gallazzi, “Un’iscrizione inedita di Tebtynis per una statua controversa di Tolomeo XII", QTNAC 18 (1989), pp. 201-09.

Belzoni, Giovan Battista, Viaggi in Egitto ed in Nubia contenenti il racconto delle ricerche e scoperte archeologiche fatte nelle piramidi nei templi nelle rovine e nelle tombe di que' paesi seguiti da un altro viaggio lungo la cos- ta del Mar Rosso e all'Oasi di Giove Ammone, Milano 1825.

Bianchi, Robert Steven, “The Striding Draped Male Figure of Ptolemaic Egypt” (dissertation, New York University), New York 1977.

Borchardt, Ludwig, Statuen und Statuetten von Königen und Privatleuten im Museum von Kairo. I, Berlin 1911.

Bothmer, Bernard V., Egyptian Sculpture of the Late Period, 700 BC to AD 100, New York 1960.

Breccia, Evaristo, “Rapport sur les fouilles de la 'Società italiana per la ricerca dei papiri greci e latini' à Oxyrhychos et à Tebtynis (1928-1930)", ASAE 31 (1931), pp. 19-24.

Brissaud, Philippe and Christiane Zivie-Coche, Tanis: travaux récents sur le Tell Sên el-Hagar. Mission française des fouilles de Tanis, 1987-1997, Paris 1998.

Brophy, Elizabeth, Royal Statues in Egypt 300 BC-AD 220: Context and Function, Oxford 2015.

Bruhn, Kai-Christian and Katja Lembke, Ammoniaca I: “Kein Tempel der Pracht”, Wiesbaden 2010.

Cafici, Giorgia, "Il volto ritrovato: identificazione del frammento scultoreo S. 19400 RCGE 48068 del Museo Egizio di Torino", EVO 39 (2016), pp. 149-61.

Davoli, Paola, L'archeologia urbana nel Fayyum di età ellenistica e romana, Napoli 1998.

Deotto, Giulia, "Il segno: reperti e campagne di scavo negli archivi" in: Paola Zanovello, Ambrogio Fassina and Emanuele M. Ciampini, Studi Egittologici in Veneto, Padova 2104, pp. 68-71.

Deotto, Giulia, “The University of Padova in Egypt: Analysis and Reconstruction of the Mission in Tebtynis Through the Unpublished Papers" (Dissertation, Università degli Studi di Padova), Padova 2015.

Deotto, Giulia, Cinzia Bettineschi, Luigi Magnini and Luca Toninello, Horus project: visioni dall'alto dello spazio archeologico, Padova 2017.

Gallazzi, Claudio, "Fouilles anciennes et nouvelles sur le site de Tebtynis”, BIFAO 89 (1989), pp. 179-91.

Gallazzi, Claudio, “Carlo Anti a Tebtynis: il lavoro svolto e le prospettive aperte”, in: Carlo Anti: giornate di studio nel centenario della nascita, Trieste 1992, pp. 129-48.

Gallazzi, Claudio, Tebtynis I. La reprise des fouilles et le quartier de la chapelle d'Isis- Thermouthis, Le Caire 2000.

Gallazzi, Claudio, "La ricerca archeologica a Umm el-Breigat (Tebtynis)”, in: Maria Casini (ed.), Cento Anni in Egitto: percorsi dell'Archeologia Italiana, Milano 2001, pp. 171-83.

Ghedini, Francesca and Federico Biondani, Carlo Anti, Villafranca di Verona 1990.

Grenfell, Bernard P. and Arthur S. Hunt, The Tebtunis Papyri, London 1902.

Grenfell, Bernard P. and Arthur S. Hunt, The Tebtunis Papyri, Part II, London 1903.

Grenfell, Bernard P. and Arthur S. Hunt, The Tebtunis Papyri, Part III, London 1933.

Guarducci, Margherita, Epigrafia greca, II, Roma 1969.

Hazzard, Richard, Ptolemaic Coins: An Introduction for Collectors, Toronto 1995.

Hölbl, Günther, A History of the Ptolemaic Empire, London 2001. 
Kyrieleis, Helmut, Bildnisse der Ptolemäer, Berlin 1975. Jucker, Ines, “Zum Bildnis Ptolemaios' III. Euergetes I.", AntKunst 18 (1975), pp. 17-25.

La R. missione archeologica italiana di Egitto scopre fra le rovine dell'antica Tebtunis nel Fayum il tempio del dio coccodrillo. Gennaio - aprile IX, documentary film, Istituto Luce 1931; MSA, Anti archive and Istituto Luce, Archivio Storico Luce, https://patrimonio.archivioluce.com/luce-web/detail/IL3000051873/1/ scavi-della-missione-archeologia-italiana-egitto-gennaio-aprile-1931 (accessed May 30, 2017).

Lembke, Katja and Günter Vittmann, “Die ptolemäische und römische Skulptur im Ägyptischen Museum Berlin. I: Privatplastik", JBM 42 (2000), pp. 7-57.

Ma, John, Statues and the Cities, Oxford 2013.

Malek, Jaromir, “The Archivist as a Researcher”, in: Jan Assmann, Eberhard Dziobek, Heike Guksch and Friederike Kampp (eds.), Thebanische Beamtennekropolen: neue Perspektiven archäologischer Forschung. Internationales Symposion, Heidelberg, 9.-13.6.1993, Heidelberg 1995, pp. 43-45.

Malek, Jaromir, "We Have the Tombs, Who Needs the Archives?”, in: Nigel Strudwick and John H. Taylor (eds.), The Theban Necropolis: Past, Present and Future, London 2003, pp. 229-43.

Ministero dell'Educazione Nazionale (ed.), Mostra d'arte antica: Roma, Galleria Nazionale a Valle Giulia, aprilegiugno 1932 (catalogue of the exhibition, Galleria Nazionale a Valle Giulia), Rome 1932.

Moiso, Beppe (ed.), Ernesto Schiaparelli e la tomba di Kha, Torino 2008.

Moiso, Beppe, “L’opera di Francesco Ballerini nelle missioni archeologiche di Ernesto Schiaparelli”, in: Anna Consonni, Tommaso Quirino and Angelo Sesana (eds.), L’Egitto di Francesco Ballerini, Como 2011, pp. 37-54.

Moiso, Beppe, "Cinque lettere di Francesco Ballerini a Ernesto Schiaparelli”, in: Anna Consonni, Tommaso Quirino and Angelo Sesana (eds.), L'Egitto di Francesco Ballerini, Como 2011, pp. 179-86.

Parlasca, Klaus, "Probleme der späten Ptolemäerbildnisse”, in: Herwig Maehler and Volker Michael Strocka (eds.), Das Ptolemäische Ägypten: Akten des internationalen Symposions, 27-29. September 1976 in Berlin, Mainz am Rhein 1978, pp. 25-30.

Perdu, Olivier, Les statues privées de la fin de l'Egypte pharaonique (1069 av. J.-C.-395 apr. J.-C.), Paris 2012.

Piacentini, Patrizia, Gli archivi egittologici dell'Università degli Studi di Milano, I:. Il fondo Elmar Edel, Milano 2006.

Piacentini, Patrizia, Victor Loret in Egypt (1881-1899): From the Archives of the Milan University to the Egyptian Museum in Cairo. Egyptian Museum in Cairo, May 19-June 30, 2008, Cairo 2008.

Piacentini, Patrizia and Christian Orsenigo, Egyptian Archives: Proceedings of the First Session of the International Congress Egyptian Archives/Egyptological Archives Milano, September 9-10, 2008, Milano 2009.

Piacentini, Patrizia, Egypt and the Pharaohs: Pharaonic Egypt in the Archives and Libraries of the Università degli Studi di Milano, Milano 2010.

Polacco, Luigi, Commemorazione del Membro Emerito prof. Carlo Anti, Venezia 1962.
Poole, Reginald Stuart, Catalogue of the Greek Coins in the British Museum: The Ptolemies, Kings of Egypt, London 1883.

Quirke, Stephen, Hidden Hands: Egyptian Workforces in Petrie Excavation Archives, 1880-1924, London 2010.

Riggs, Christina, "Photography and Antiquity in the Archive, or How Howard Carter Moved the Road to the Valley of the Kings", History of Photography 40 (2016), pp. 267-82.

Riggs, Christina, "The Body in the Box: Archiving the Egyptian Mummy”, Archival Science 17. 2 (2017), pp. $125-50$.

Riggs, Christina, "Shouldering the Past: Photography, Archaeology, and Collective Effort at the Tomb of Tutankhamun", HistSc 2016 (epub ahead of print). https://doi.org/10.1177/0073275316676282.

Rondot, Vincent, Tebtynis II: le Temple de Soknebtynis et son dromos, Le Caire 2004.

Rubensohn, Otto, “Aus griechisch-römischen Häusern des Fayum”, JDAI 20 (1905), pp. 1-25.

Russmann, Edna, Eternal Egypt: Masterworks of Ancient Art from the British Museum, London 2001.

Sbriglio, Alice, "Gli scavi Schiaparelli a Eliopoli (1903-1906): gli amuleti provenienti dal kom” (School of Specialization in Archaeology Thesis, Università degli Studi di Milano), Milano 2014.

Sbriglio, Alice and Federica Ugliano, "Re-excavating Heliopolis: Unpublished Archaeological Data from the Archives of Ernesto Schiaparelli and Missione Archeologica Italiana”, in: Massimiliano Samuele Pinarello, Justin Yoo, Jason Lundock and Carl Walsh (eds.), Current Research in Egyptology 2014: Proceedings of the Fifteenth Annual Symposium. University College London and King's College London (April 9-12, 2014). Oxford 2015, pp. 278-93.

Smith, R. R. R., Hellenistic Royal Portraits, Oxford 1988. Stanwick, Paul Edmund, "A Royal Ptolemaic Bust in Alexandria”, JARCE 29 (1992), pp. 131-41.

Stanwick, Paul Edmund, Portraits of the Ptolemies: Greek Kings as Egyptian Pharaohs, Austin 2002.

Svoronos, Ioannes, Die Münzen der Ptolemäer, IV. Deutsche Übersetzung des I. Bandes, Athen 1908.

Ugliano, Federica, "La collezione predinastica del Museo Egizio di Torino: uno studio integrato di archivi e reperti" (PhD dissertation, Università degli Studi di Trento), Trento 2015.

Valtz, Elisabetta, "Italian Excavations at Tebtynis 1930-1935: The Objects at Egyptian Museum, Torino", in: Sesto congresso internazionale di Egittologia: Atti, Torino 1992, pp. 625-28.

Vogliano, Achille, Un'impresa archeologica milanese ai margini orientali del Deserto libico, Milano 1942.

Warda, Aleksandra, "Egyptian Draped Male Figures, Inscriptions and Context: 1st century BC-1st century AD"(dissertation, University of Oxford), Oxford 2012.

Zampieri, Girolamo (ed.), Diari ed altri scritti di Carlo Anti, I-II, Verona 2009.

Zampieri, Girolamo (ed.), Diari di Carlo Anti, rettore dell'Università di Padova e direttore generale delle arti della Repubblica Sociale Italiana, Verona 2011.

Zanovello, Paola and Giulia Deotto, "Carlo Anti e Tebtynis”, in: Paola Zanovello and Emanuele 
Marcello Ciampini (eds.), Egitto in Veneto (catalogue of the exhibition, Padova- Rovigo, 12 April 2013-30 June 2013), Padova 2013, pp. 39-47.

Zanovello, Paola, "L'archivio Anti e reperti da Tebtynis
all'Università di Padova”, in: Paola Zanovello, Ambrogio Fassina and Emanuele Marcello Ciampini (eds.), Studi Egittologici in Veneto, Padova 2014, pp. 67-68. 